$$
\begin{gathered}
\text { PELA } \\
\text { DEL U O } 1595 \\
\text { OSTI }
\end{gathered}
$$

\title{
A Primer on Incentive Regulation for Electric Utilities
}

Lawrence J. Hill

MANAGED BY

LOCKHEED MARTIN ENERGY SYSTEMS, INC. FOR THE UNITED STATES

DEPARTMENT OF ENERGY

UCN-13673 (38 6-95) 
This report has been reproduced directly from the best available copy.

Available to DOE and DOE contractors from the Office of Scientific and Technical Information, P.O. Box 62, Oak Ridge, TN 37831; prices available from (615) 576-8401, FTS 626-8401.

Available to the public from the National Technical Information Service, U.S. Department of Commerce, 5285 Port Royal Rd., Springfield, VA 22161.

This report was prepared as an account of work sponsored by an agency of the United States Government. Neither the United States Government nor any agency thereof, nor any of their employees, makes any warranty, express or implied, or assumes any legal liability or responsibility for the accuracy, completeness, or usefulness of any information, apparatus, product, or process disclosed, or represents that its use would not infringe privately owned rights. Reference herein to any specific commercial product, process, or service by trade name, trademark, manufacturer, or otherwise, does not necessarily constitute or imply its endorsement, recommendation, or favoring by the United States Government or any agency thereof. The views and opinions of authors expressed herein do not necessarily state or reflect those of the United States Government or any agency thereof. 


\title{
A PRIMER ON INCENTIVE REGULATION FOR ELECTRIC UTILITIES
}

Lawrence J. Hill

Energy Division

October 1995

\author{
Sponsored by \\ Competitive Resource Strategies Program \\ Office of Energy Efficiency and Renewable Energy \\ U.S. Department of Energy \\ OAK RIDGE NATIONAL LABORATORY \\ Oak Ridge, Tennessee 37831 \\ Managed by \\ LOCKHEED MARTIN ENERGY SYSTEMS, INC. \\ for the \\ U.S. DEPARTMENT OF ENERGY \\ under Contract No. DE-AC05-84OR21400
}


,

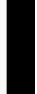




\section{CONTENTS}

LIST OF FIGURES AND TABLES $\ldots \ldots \ldots \ldots \ldots \ldots \ldots \ldots \ldots \ldots \ldots$

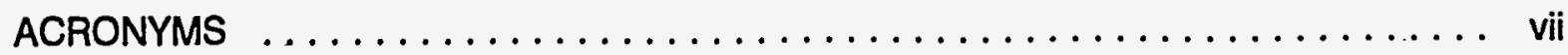

PREFACE $\ldots \ldots \ldots \ldots \ldots \ldots \ldots \ldots \ldots \ldots \ldots \ldots \ldots \ldots \ldots \ldots \ldots \ldots$

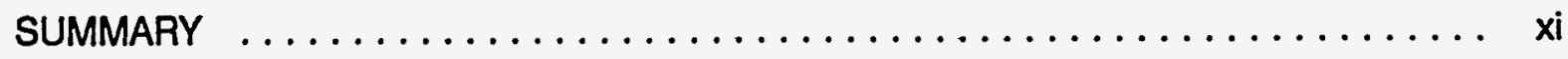

1. INTRODUCTION $\ldots \ldots \ldots \ldots \ldots \ldots \ldots \ldots \ldots \ldots \ldots \ldots \ldots \ldots \ldots$

1.1. What is Incentive Regulation? . . . . . . . . . . . . . . . 1

1.2. Why are Regulators Switching to Performance-Based Regulation? .... 1

1.3. What is the Experience with Performance-Based Regulation? ....... 3

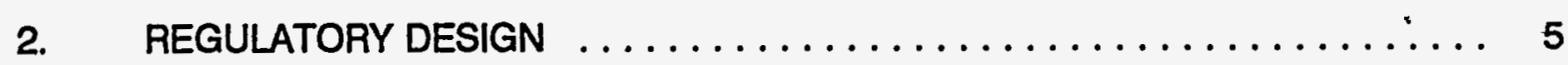

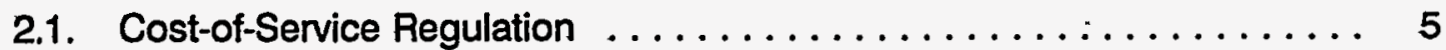

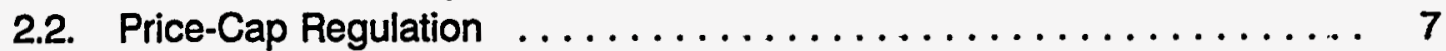

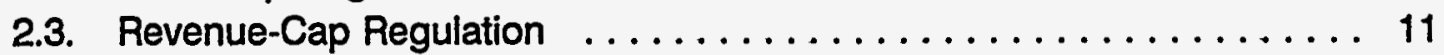

2.4. Rate-of-Return Bandwidth Regulation $\ldots \ldots \ldots \ldots \ldots \ldots \ldots \ldots \ldots$

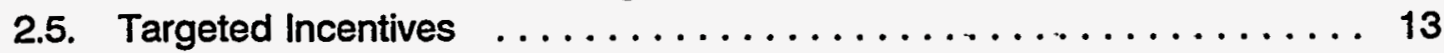

2.6. Mixed Regulatory Approaches $\ldots \ldots \ldots \ldots \ldots \ldots \ldots \ldots \ldots \ldots \ldots$

3. IMPLEMENTATION ISSUES $\ldots \ldots \ldots \ldots \ldots \ldots \ldots \ldots \ldots \ldots \ldots \ldots$

3.1. Number of Caps $\ldots \ldots \ldots \ldots \ldots \ldots \ldots \ldots \ldots \ldots \ldots \ldots \ldots$

3.2. Measuring Inflation and Productivity for Caps $\ldots \ldots \ldots \ldots \ldots \ldots 18$

3.3. "Z" Factors for Caps . . . . . . . . . . . . . . . . . . . 22

4. INCENTIVES UNDER PERFORMANCE-BASED REGULATION $\ldots \ldots \ldots \ldots 25$

4.1. To Lower the Cost of Producing Electricity $\ldots \ldots \ldots \ldots \ldots \ldots \ldots$

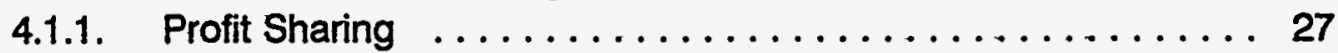

4.1.2. Time Between Rate Cases .................. 30

4.1.3. Level of Price Caps ..................... 30

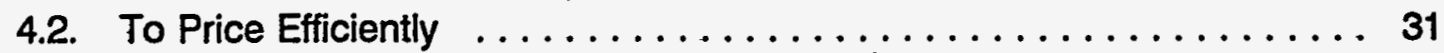

4.3. To Promote Energy Efficiency $\ldots \ldots \ldots \ldots \ldots \ldots \ldots \ldots \ldots \ldots \ldots \ldots \ldots \ldots$

4.4. To Improve Service Quality .................... 34

5. CONSISTENCY WITH FINANCIAL ACCOUNTING STANDARDS $\ldots \ldots \ldots$

6. CONCLUSIONS $\ldots \ldots \ldots \ldots \ldots \ldots \ldots \ldots \ldots \ldots \ldots \ldots \ldots \ldots \ldots$

REFERENCES $\ldots \ldots \ldots \ldots \ldots \ldots \ldots \ldots \ldots \ldots \ldots \ldots \ldots \ldots \ldots \ldots \ldots \ldots$ 


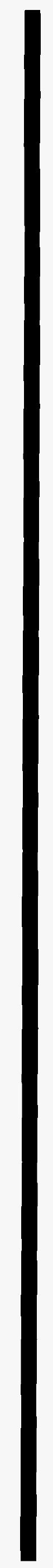




\section{LIST OF FIGURES AND TABLES}

Figure

Description

Page

\begin{tabular}{cc}
\hline 1 & Accounting Cost-Allocation Example $\ldots \ldots \ldots \ldots \ldots \ldots \ldots \ldots \ldots$
\end{tabular}


ACRONYMS

\begin{tabular}{|c|c|}
\hline Acronym & Description \\
\hline APC & Alabama Power Company \\
\hline CMP & Central Maine Power Company \\
\hline COSR & Cost-of-Service Regulation \\
\hline DSM & Demand-side management \\
\hline IRP & Integrated resource planning \\
\hline kWh & Kilowatt-hour \\
\hline LRMC & Long-run marginal cost \\
\hline MPUC & Maine Public Utilities Commission \\
\hline NMPC & Niagara Mohawk Power Corporation \\
\hline NYSE\&G & New York State Electric and Gas \\
\hline PBR & Performance-based regulation \\
\hline PCR & Price-cap regulation \\
\hline RCR & Revenue-cap regulation \\
\hline ROE & Return on Equity \\
\hline ROR & Rate of Return \\
\hline SDG\&E & San Diego Gas and Electric \\
\hline TEPCO & Tucson Electric Power Company \\
\hline
\end{tabular}




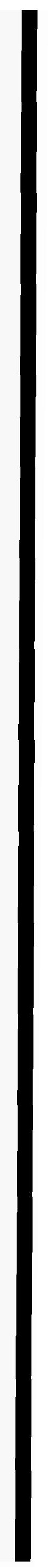




\section{PREFACE}

This primer addresses the design, implementation, and incentives of different regulatory models for electric utilities. Throughout, we attempt to simplify economic concepts, rather than study them in detail. As such, the primer is intended as a "road map" through the comparative design of alternative approaches to regulating electric utilities. In doing so, we make the topic of regulation accessible to a wide audience. It is written primarily for regulatory and utility policy decisionmakers. However, for technical utility and regulatory staff, as well as the academic community, we feel the primer is a good introduction to incentive regulation.

Future work sponsored by the U.S. Department of Energy's Comparative Resource Strategies Program will provide additional analyses of actual filed plans and specific issues that arise in the design of regulatory models. This forthcoming report is intended specifically for technical regulatory and utility staff faced with the problem of designing a regulatory model for an electric utility (Comnes et al., 1995).

We thank the following for providing very useful reviews of an earlier version of this primer: Jasmin Ansar, Pacific Gas and Electric Company; Alan Comnes, Lawrence Berkeley Laboratory; Anne Eakin, PacifiCorp; Ken Gordon, Massachusetts Department of Public Utilities; Mohammad Harunuzzaman, National Regulatory Research Institute; Eric Hirst, Oak Ridge National Laboratory; Val Jensen, U.S. Department of Energy; Wayne Olson, Maine Public Service Commission; Dennis Ray, Wisconsin Public Utilities Institute; and John Scadding, California Public Utilities Commission. 


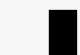




\section{SUMMARY}

In contemplating a regulatory approach, the challenge for regulators is to develop a model that provides incentives for utilities to engage in socially desirable behavior. In this primer, we provide guidance on this process by discussing (1) various models of economic regulation, (2) problems implementing these models, and (3) the types of incentives that various models of regulation provide electric utilities.

We address five regulatory models in depth. They include cost-of-service regulation in which prudently incurred costs are reflected dollar-for-dollar in rates and four performance-based models: (1) price-cap regulation, in which ceilings are placed on the average price that a utility can charge its customers; (2) revenue-cap regulation, in which a ceiling is placed on revenues; (3) rate-of-return bandwidth regulation, in which a utility's rates are adjusted if earnings fall outside a "band" around equity returns; and (4) targeted incentives, in which a utility is given incentives to improve specific components of its operations. The primary difference between cost-of-service and performance-based approaches is the latter sever the tie between costs and prices.

A sixth, "mixed approach" combines two or more of the five basic ones. In the recent past, a common mixed approach has been to combine targeted incentives with cost-of-service regulation. A common example is utilities that are subject to cost-of-service regulation are given added incentives to increase the efficiency of troubled electric-generating units.

Under current pending and approved performance-based approaches, "pure" price- or revenue-cap regulation is combined with a rate-of-return bandwidth, serving both as a "check" on a utility's profits and as a mechanism for a utility and its ratepayers to share very high or low returns. Also, most of these mixed cap-bandwidth models provide targeted incentives for utilities to engage in specific types of behavior. Incentives for running demand-side management programs and maintaining or improving service quality are common in these models.

Three regulatory-design features provide the greatest incentives for utilities to reduce costs. First, within limits in profit-sharing arrangements, the greater the percentage of profits going to a utility, the greater is the incentive for the utility to reduce costs. Second, within limits, the lower the price caps, the greater is the incentive for a utility to make cost-reducing investments. Third, the longer the interval between regulatory review of a utility's rates, the more likely the utility is to reduce costs.

The length of time between rate reviews is important for another reason. With greater pricing flexibility and longer periods of time between reviews under performance-based regulation, a utility is more likely to price efficiently.

On the other hand, performance-based approaches such as price- and revenue-cap regulation will converge to cost-of-service regulation with shorter lengths of time between rate reviews and less flexibility in setting individual prices. At the extreme, realigning costs with prices 
under performance-based approaches at periodic intervals during rate reviews by allocating common costs to individual rate classes will lead to more inefficient utility behavior.

Along the same line, passing certain items of costs to ratepayers on a dollar-for-dollar basis (i.e., using " $Z$ " factors) moves performance-based approaches toward cost-based ones. The closer prices reflect costs in this way, the more likely performance-based regulation will converge to cost-of-service regulation.

With the electric industry changing rapidly, the challenge for policymakers in the future will be to design regulatory models consistent with the restructured industry. With the generating portion of the industry becoming competitive and deregulated in many parts of the country, the challenge will be to devise effective regulatory models for the still-regulated, natural-monopoly portion of the industry. 


\section{INTRODUCTION}

\subsection{WHAT IS INCENTIVE REGULATION?}

All forms of economic regulation are variants of incentive regulation, including traditional cost-of-service regulation (COSR) and newer performance-based approaches such as price- and revenue-cap regulation (PCR and RCR). The distinguishing characteristics of the different forms are the types of incentives that they provide to regulated firms. Different incentives to minimize cost, to innovate, to promote public-policy goals, and to price efficiently are important differentiating characteristics of regulatory forms.

Unfortunately, the term "incentive regulation" is oftentimes used to characterize the newer performance-based approaches, overlooking the powerful incentives in traditional COSR. In this primer, we divide "incentive regulation" into two parts: (1) traditional COSR and (2) the newer performance-based approaches that provide financial rewards for a utility's performance.

In a general sense, the distinction between COSR and PBR is the degree to which costs are reflected in a utility's rates. Under "pure" COSR, there is in principle a dollar-for-dollar correspondence between prudently incurred costs and rates. Under PBR, the link between costs and rates is not as direct in the short term, depending on the type of PBR form and the length of time between rate reviews.

Specifically, the distinction between COSR and comprehensive PBR such as PCR and $R C R^{1}$ is that the latter typically allow utilities to-

1. price their services flexibly to meet the prices of their competitors.

2. continue to have monopoly power in some of their markets, requiring a ceiling to be placed on the prices that utilities can charge any set of customers.

3. be protected against inflation and other factors beyond their control, allowing ceiling prices to change automatically over time.

\subsection{WHY ARE REGULATORS SWITCHING TO PERFORMANCE-BASED REGULATION?}

As it has evolved at the state level, electric utilities must submit to regulation of their rates, service, and safety by state commissions as a condition for obtaining franchise monopolies in defined geographical areas. By far, the most controversial of all regulatory areas is rates: How are electricity rates to be determined, and at what levels should they be set?

To address the rate challenge, COSR has been historically adopted by most state

${ }^{1}$ In Section 2, we discuss six regulatory models, with the sixth being a combination of the other five. The four performance-based approaches are price-cap regulation, revenue-cap regulation, rate-of-return bandwidth regulation, and targeted incentives. The first three PBR approaches are comprehensive in that they affect a utility's total operations. 
regulatory commissions. Concisely, COSR allows electric utilities to recover all prudently incurred operating costs plus a reasonable opportunity to earn a fair return on their investment in electric plant when setting rates. Three features of COSR make it attractive for regulators. First, rates are based on accounting costs, information that utilities gather as a matter of course. Second, because utilities are allowed to recover their costs, they are likely to maintain and even improve service quality. Third, the regulatory process allows a fair return on the franchise monopoly's investment in plant and equipment, neither confiscating it over time nor allowing an excess return.

Then, why replace COSR with another approach based on performance? The problems with the cost-of-service approach are the incentives and opportunities given to electric utilities. They are not the type of incentives that characterize a competitive market, and that balance the additional risk of operating in a competitive market. Under COSR, the incentives to operate "efficiently" in the sense of an unregulated firm are minimal.

Incentives and opportunities to invest wisely in utility plant and equipment are also distorted under COSR. In contrast to a competitive market, COSR does not generally reward utilities with a higher return for making an especially good investment in plant and equipment, or penalize them for making an especially bad investment. The return that a utility earns on a highly successful investment is generally the same as its return on a less-successful one. The opportunity to prosper--or, alternatively, to go bankrupt--is generally not part of COSR.

Some states have attempted to correct the distorted incentives resulting from COSR by introducing variants of PBR. Most of these early attempts, however, have not been comprehensive, focusing instead on select aspects of an electric utility's operations. The performance of troubled generating units was a popular target in early PBR attempts. Financial incentives in the form of higher allowed revenues (and, therefore, higher returns for stockholders) were provided to electric utilities for increasing the efficiency of troubled plants. More recently, state regulators have targeted demand-side management (DSM) programs, providing financial incentives for electric utilities to invest in these types of conservation and load management programs.

Congress enacted the Energy Policy Act in 1992 in part to facilitate change in the business of generating electricity, hoping to correct some of the distortions and inefficiencies targeted by some states in these early PBR attempts. One goal of the legislation is to enable the most efficient "business firms"--not necessarily electric utilities in the traditional sense--to produce electricity. By amending the Public Utility Holding Company Act of 1935, the legislation creates the "exempt wholesale generator"-a new type of electric firm--to compete with electric utilities in the power-generation market. To facilitate competition further, the Energy Policy Act also opens access to electric transmission lines, allowing electric firms other than the lines' utility-owners to transmit power for resale to other utilities or power distributors. The Federal Energy Regulatory Commission's recent Notice of Proposed Rulemaking on transmission access implements 
EPAct's mandate. 2

As a result of these federal initiatives, advances in electric-turbine technologies, and lower gas prices, many existing electric utilities are no longer expected to be vertically integrated, regulated monopolies in the future--i.e., generating, transmitting, and distributing a large share of their own power needs. Competition will evolve over time to displace regulation as an important mechanism for allocating resources for the generation of electricity by power plants. Over time, utilities that produce power less efficiently than their competitors are likely to become a type of electricity retailer, purchasing power from other generating firms (i.e., wholesalers) and selling that power to their traditional customers.

In this emerging competitive environment, PBR may well be the best bridge between COSR, in which rates are determined in a regulatory proceeding, and a situation in which rates are determined in unregulated markets. Under PBR, regulators give electric utilities more flexibility in setting rates to meet the prices of its competitors, while still controlling market power.

\subsection{WHAT IS THE EXPERIENCE WITH PERFORMANCE-BASED REGULATION TO DATE?}

Utilities in Britain were among the first in the world to be subject to full-scale, nonexperimental PBR approaches. ${ }^{3}$ British Telecom was placed under PCR in 1984. It is now in its third revision of that plan, covering the period 1993-1997. British Gas was placed under PCR in 1987. It is now in its second revision, covering the years 1994-1997. British electric utilities were placed under PCR in 1990 for a five-year period. The second revision of that plan is currently in the process of being developed.

In the United States, American Telephone and Telegraph was placed under PCR in 1989. GTE and Pacific Bell in California followed in 1990. Many other intra-state telecommunications companies have followed. ${ }^{4}$

Natural gas distribution utilities are also increasingly being placed under various forms of PBR. Utilities such as Brooklyn Union Gas Company and Wisconsin Gas Company have plans in place, while other local distribution utilities have PBR proposals pending. ${ }^{5}$

Comprehensive PBR in the electric power industry is spotty. Only a handful of the 254 investor-owned utilities currently have pending or approved PBR plans. Three California utilities

\footnotetext{
${ }^{2}$ Federal Energy Regulatory Commission (1995).

${ }^{3}$ See Beesley and Littlechild (1989) for a description of the privatization and creation of regulatory models for British utilities.

${ }^{4}$ See Christensen Associates (1994) for more details on the U.S. telecommunications industry.

${ }^{5}$ See Comnes (1994) for a description of some of these plans.
} 
(San Diego Gas and Electric, Southern California Edison, and Pacific Gas and Electric) have developed comprehensive plans, but at this writing only SDG\&E's has been approved by the California Public Utilities Commission. The others are on hold, pending California's restructuring policy. Central Maine Power (CMP) has a price-cap plan in place for a five-year period beginning on January 1, 1995. Mississippi Power and Light and Alabama Power Company have had rateof-return bandwidth plans in effect since the 1980s. Niagara Mohawk Power Company proposed a price-cap plan in February, 1994, the resolution of which is still pending. ${ }^{6}$ In addition, many other electric utilities have less comprehensive PBR programs, targeted at specific aspects of their operations.

${ }^{6}$ These approved and pending plans are discussed in greater detail in Comnes et al. (1995). 


\section{REGULATORY DESIGN}

In this section, we examine the basic design of five regulatory approaches: (1) COSR, (2) PCR, (3) RCR, (4) rate of return (ROR) bandwidth regulation, and (5) targeted incentives. A sixth "mixed" approach is a combination of two or more of the first five.

The approach we use to describe the design features is expository in nature, not derivative. That is, we emphasize how important regulatory relationships are expressed in practice, not how they are derived in theory. We sprinkle real-world examples of pending and approved plans throughout the discussion, helping the reader to understand better how the approaches are used in practice.

\subsection{COST-OF-SERVICE REGULATION}

As historically practiced by most electric utilities, the prices for classes or "baskets" of electric service (such as for low-income residential customers or high-demand industrial customers) under COSR reflect some measure of their accounting costs. Typically, these prices are fixed: they are both ceilings and floors for the ratepayers of electric utilities because utilities do not have the flexibility to change them.

There are usually two parts to the process of determining these prices. First, the utility estimates the total amount of (annual) revenues needed to maintain its financial viability. This procedure includes determining the total cost of providing electricity, including a ROR that is (1) sufficient to compensate contributors of capital (owners and creditors) for their investment and (2) large enough to attract new capital. The second procedure involves determining the structure of rates charged to individual customers or classes of customers-given the overall level of required revenues. This aspect of COSR requires allocating total accounting costs determined in the first part of the ratemaking process to each class of customers such that each class earns a sufficient ROR and no class of service subsidizes another. Because of the difficulty in allocating accounting costs, this is often very difficult in practice.

In accounting terms, the required revenues (RR) for an electric utility in time t are the sum of its operating costs and capital costs: ${ }^{7}$

$$
R R_{t}=O E_{t-1}+D_{t-1}+T_{t-1}+\left(R B^{\star} R O R\right)_{t-1}
$$

$$
\text { where } \begin{aligned}
& O E=\text { Operating expenses, } \\
& D=\text { Depreciation expense, } \\
& T=\text { Tax expense, } \\
& \text { RB }=\text { Rate base, }
\end{aligned}
$$

${ }^{7}$ In what follows, we describe rates based on historical accounting costs. In practice, these rates could be based on projected costs. In either case, however, the procedure for determining rates for individual customer classes is the same. 
ROR $=$ Rate of return.

A utility is allowed to earn revenues to recover all expenses (OE, $D$, and $T$ ) plus a return on investment in useful plant and equipment (RB * ROR).

Once an estimate of the over-all level of required revenues is obtained, total costs are assigned to different classes of service. Prices for each class of a utility's service are the ratios of allocated costs to historical--or estimated-sales. Because the assigned costs are typically accounting costs rather than economic costs, there is usually some arbitrariness in assigning them to individual customer groups.

Figure 1 contains an example of allocating accounting costs to individual customer groups under cost-based ratemaking. Generation, transmission, distribution, and other costs are assigned to customer classes either directly or functionally. An example of direct allocation is the "customer costs" for residential customers consuming less than $500 \mathrm{kWh}$ per month. These costs are easily obtainable from existing accounting records. Most categories of costs, however, are not easily obtainable from accounting records because they are joint costs, attributable to more than one customer class. In Figure 1, we show one possible allocation by (1) number of customers, (2) amount of energy consumed, and (3) contribution to the utility's peak load. From this cost-allocation process, the price (P) for any customer group or basket of services $n$ (e.g., prices for residential customers) in year $t$ can be expressed as follows:

$$
P_{n, t}=\left(O E_{n, t-1}+D_{n, t-1}+T_{n, t-1}+\left(R B^{*} R O R\right)_{n, t-1}\right) / \text { Sales }_{t-1}
$$

where Sales are the amount of kWh sales and OE, D, T, and RB*ROR were defined in the context of equation (1). Alternatively, equation (3) can be expressed as follows:

(3) $\quad P_{n, t}=C_{n, t-1} /$ Sales $_{n, t-1}$,

where $C_{n, t-1}$ is the total allocated accounting cost for service $n$ in year $t-1$.

The relationship in equation (3) suggests that prices in year t reflect the prior-year's costs $(t-1)$. In reality, this is an oversimplification. First, as the previous footnote indicates, many utilities project future costs in determining rates. Second, rate hearings are not typically conducted annually. Therefore, for most utilities, there is often a "lag" longer than a year between the period when costs are incurred and the period on which rates are based. Using equation (3), the price of service $n$ in the yeat $t$ is based on costs incurred more than a year ago:

(4) $\quad P_{n, t}=C_{n, t-x} /$ Sales $_{n, t-x}$,

where $x>1$. 
Figure 1

Accounting-Cost Allocation Example

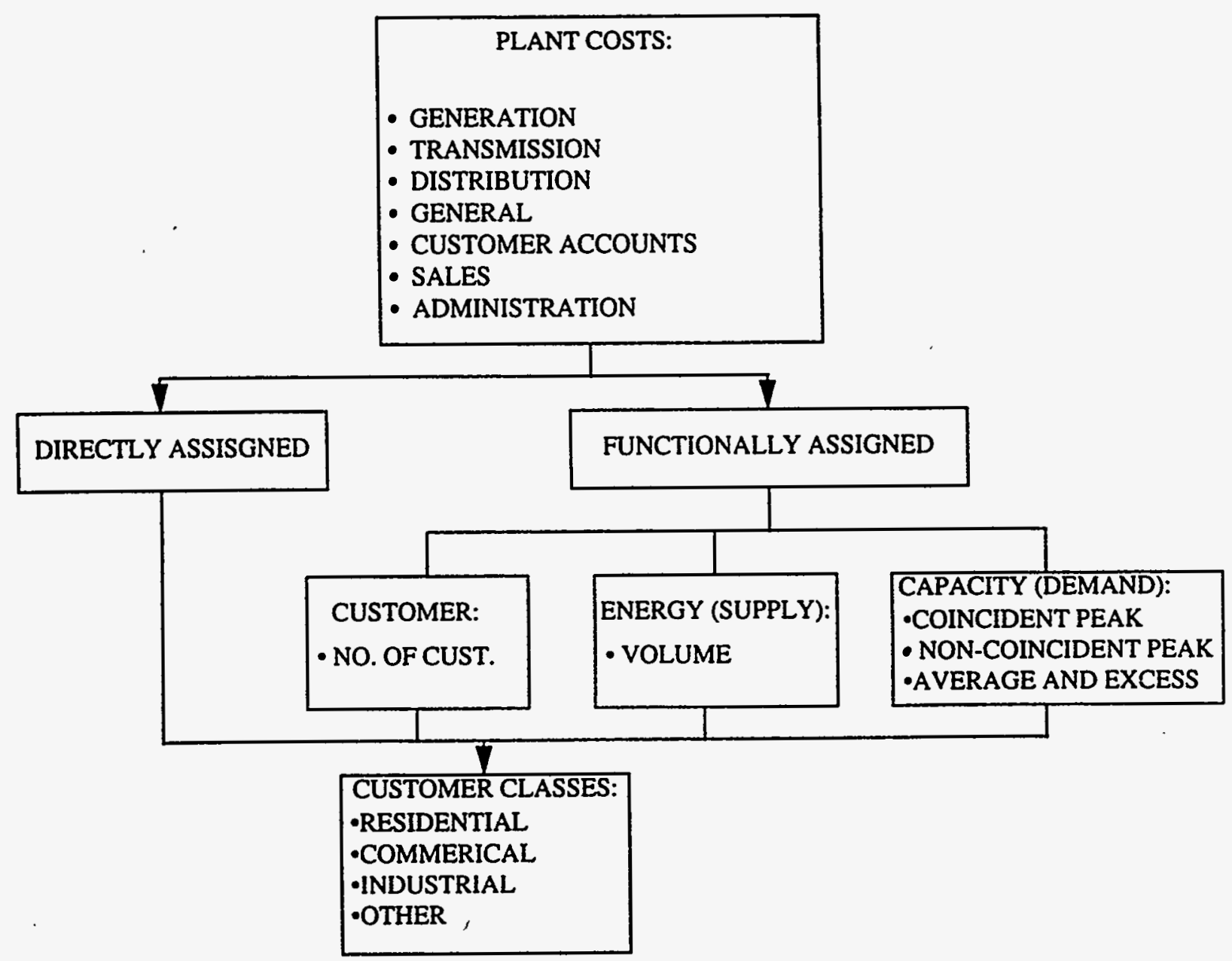

\subsection{PRICE-CAP REGULATION}

As discussed in Section 1.2, a major criticism of COSR is that it provides distorted incentives to utilities. From equation (3), given that prices for any class of service reflect allocated accounting costs, there is little incentive for a utility to minimize its costs under "pure" COSR. This is true both in the short-term and over the longer term in which investments could be made to reduce costs. Another problem is the inflexibility of prices. Under COSR, utilities are not generally allowed to price to meet their competition. 
If the cost-price relationship and inflexibility is a concern, the challenge for policymakers is to develop a regulatory mechanism that does not rely on a dollar-for-dollar correspondence between costs and prices. "Pure" PCR is one such mechanism.

Like COSR, the prices for individual baskets of service under PCR are ceilings. Unlike COSR, they are not also floors. A utility is given the flexibility to price below the ceiling to some predefined floor. The marginal cost of providing the service--either short run or long run marginal cost, depending on the customer group or "basket" under consideration--is one such floor. To further sever the cost-price relationship, the procedures for regulatory review of a utility's financial condition also change. Regulatory reviews are typically conducted at predefined intervals under PCR (e.g., every five years), rather than triggered by cost considerations. This is a further incentive for a utility to cut costs.

In practice, two issues arise. First, initial ceiling prices must be established. The initial prices are typically determined from a cost-of-service rate case in a manner similar to that described above for COSR. Therefore, initial or starting prices for each class or basket of service are typically based on allocated accounting costs.

Second, if a price ceiling is imposed and regulatory reviews occur infrequently, utilities are typically protected from cost increases beyond their control. Thus, the ceiling prices are typically indexed to a measure of inflation over the period of time in which regulators do not review the utility's financial condition.

Therefore, instead of basing prices on costs as for COSR in equation (3), repeated here,

(3) $P_{n, t}=C_{n, t-1} /$ Sales $_{n, t-1}$

prices under PCR are allowed to increase automatically based on some index of price increases in the general economy (I):

(5) $\quad P_{n, t}=P_{n, t-1} *(1+l)$.

In practice, changes to price ceilings could be made on a quarterly, semi-annual, or annual basis. Therefore, ceiling prices in year $t$ change at the same rate as some measure of general price changes. Of course, the actual prices charged by utilities to its customers must be at or below the ceiling, and depend on competition and the pricing floor set by regulators.

Comparing equation (3) and (5) is instructive. Firșt, the link between a utility's costs and the prices it can charge its ratepayers is broken under PCR. The ceiling price for any service is based on an index of cost changes. Second, and related to the cost-price decoupling, the ceiling price for any service is not based on a utility's changes in costs, but rather on a more 
general index of the costs of all electric utilities, or those in surrounding areas. ${ }^{8}$

In practice, there are two possibilities for choosing values of $\mathrm{l}$, each of which is justified in theory. The first is to change the price caps of an electric utility using an index of electricity prices for other utilities. The other utilities could be in surrounding service territories, states, or the nation as a whole. For example, Pacific Gas and Electric Company's (PG\&E's) proposed tariffs for some of its large customers are based on an index of electricity market prices. They propose to use the national producer price index for industrial electric power as the indexing measure.

Second, instead of using an index of the retail price of electricity, an index of input costs could be used. That is, it is possible to develop a weighted index for the cost of capital, labor, energy, and other inputs used by electric utilities to produce electricity on either a regional or national basis.

A problem with using an input-cost index is that costs during any given period do not necessarily grow in direct proportion to the amount of capital, labor, and energy inputs used, or to the amount of output produced. If a utility uses its inputs more productively, costs will grow less than the amount of inputs used. If it uses them less productively, the opposite is true. Therefore, changes in productivity--defined as the ratio between amounts of output and amounts of inputs--must be accounted for. Changes in productivity alter equation (5) in the following way:

(6) $P_{n, t}=P_{n, t-1} *(1+I-p)$,

where $\mathrm{I}$ is the index for input-cost increases and $\mathrm{p}$ represents productivity.

This input-cost indexing approach is currently being used in the railroad industry. It is also being used in PacifiCorp's recently approved three-year price-cap plan, consisting of an input-price index for capital, labor, fuel, and other inputs. The productivity offset, $p$, is set at 1.4 percent per year.

An alternative to using an electric-utility input-price index is to use an index of general price changes in the economy, such as the GDP implicit price deflator or the consumer price index. A problem with this approach, however, is adjusting for the difference between electricindustry and economy-wide productivity. Using an economy-wide measure of inflation to reflect input-cost increases for a utility requires some adjustment for productivity changes. An economywide measure of inflation for outputs has national productivity changes contained in it implicitly. However, these are for all sectors of the economy. To obtain the proper productivity index for equation (6), the difference between productivity changes in the general economy and that of the electric power sector must be used. Equation (6) then becomes:

\footnotetext{
${ }^{8}$ Indexing price changes on measures of inflation reflecting all utilities or a sub-group of utilities is a form of "yardstick regulation."
} 


$$
P_{n, t}=P_{n,-1} *\left(1+1-\left(p_{G}-P_{E}\right),\right.
$$

where $I$ is an index of economy-wide inflation, $P_{G}$ is a measure for productivity in the general economy, and $P_{E}$ is a measure of productivity for the electric power sector.

Niagara Mohawk Power Company's (NMPC's) proposed price-cap plan uses this approach. Under NMPC's proposal, the price index to reflect changes in capital, labor, energy, and materials costs is the consumer price index for all goods and all urban consumers. The annual productivity offset for equation (7) is 0.2 for all periods from 1996 through 1999 . The offset is the difference between the estimated productivity for the entire U.S. economy and electric utilities in the Northeast for the latest ten-year period for which data were available. The U.S. economy's productivity is the average rate of change in the Bureau of Labor Statistics' multifactor productivity index of the U.S. private business sector. The productivity factor for electric utilities was estimated by NMPC using data for 26 of the 28 largest investor-owned utilities in the Northeast over the 1980-1990 period. The 0.2 productivity offset is the difference between the average rate of change in productivity of the U.S. economy from 1980-1990 $(0.87 \%)$ and that of the 26 utilities in the Northeast (1.10\%).

In practice, the precision used to measure the value of productivity varies. In fact, the value(s) for the productivity variables in equations (6) and (7) are often set to provide incentives for cost reduction. Clearly, from equations (6) and (7), the higher the value of $p$, the lower the rate of increase in price ceilings and, therefore, the more incentive for utilities to cut costs to increase profits. ${ }^{9}$ Used in this way, $\mathrm{p}$ is a "stretch factor." The value of the productivity variable is increased beyond its measured value, lowering the annual increase in price ceilings and, therefore, providing more incentives for utilities to cut costs.

The Maine Public Utility Commission is using the productivity offset in this way for CMP's five-year price-cap plan. Like NMPC's proposed price-cap plan, it uses the CPI to index pricecap increases on an annual basis. Its productivity offset is 0.5 percent in the first year of the plan, and 1.0 percent in the remaining years of the plan's life.

The problems and effects of using different measures of inflation and productivity on the financial condition of electric utilities subject to PCR will be discussed in greater detail in Section 3.2. There, we will discuss possible measures of inflation and productivity that a utility could use in PCR and present their values.

Finally, as PCR has evolved in practice, utilities have been allowed to recover the costs of certain items that regulators have an obligation to allow utilities to recover (such as deferred "regulatory assets"). These costs are flowed-through directly to prices. They affect the price-cap equation as follows:

\footnotetext{
9Theory suggests, however, that there is some threshold value of prices which will negate a utility's incentive to make cost-reducing investments. This topic is discussed further in Section 4.1.
} 
(8) $P_{n, t}=P_{n, t-1} *(1+1-p \pm Z)$,

where $Z$ represents the value of these costs directly affecting price ceilings. These so-called " $Z$ " factors will be discussed in more detail in Section 3.3.

\subsection{REVENUE-CAP REGULATION}

Disaggregating $P_{t}$ and $P_{t-1}$ of equation (6) into their revenue and sales components results in the following:

$$
\frac{\operatorname{Rev}_{n, t}}{k W h_{n, t}}=\frac{\operatorname{Rev}_{n, t-1}}{k W h_{n, t-1}} *(1+1-p),
$$

where $\operatorname{Rev}_{n, t}$ is the amount of revenues for basket $n$ in time $t$ and $k W h_{n, t}$ is the amount of $k W h$ sales for basket $n$ in time $t$. Recognizing that $k W h$ sales in time periods $t$ and $t-1$ can be expressed as a growth rate, equation (9) can be written as:

$$
\operatorname{Rev}_{n, t}=\operatorname{Rev}_{n, t-1} *\left(1+1-p+G_{t}\right) \text {, }
$$

where $G_{t}$ is the growth rate in sales from period $t-1$ to period $t$. Assuming that revenues in equation (10) and prices in equation (6) start at the same point, the relationships in equations (10) and (6) are equivalent. From equation (10), revenues are capped instead of prices.

However, if some other measure of the growth of a utility were substituted for the kWhgrowth rate expressed in equation (10), the results in equations (6) and (10) would not necessarily be the same. The growth in customers, for example, can be used as a substitute for $\mathrm{kWh}$ sales in equation (10). If customers (Cust) were substituted for $\mathrm{kWh}$-sales and the terms rearranged, we obtain the following:

$$
\frac{\operatorname{Rev}_{n, t}}{\text { Cust }_{n, t}}=\frac{\operatorname{Rev}_{n, t-1}}{\text { Cust }_{n, t-1}} *(1+1-p) \text {. }
$$

Clearly, changing the "driver" from kWh-sales to customers on which revenues are based from equation (10) to (11), can alter a utility's incentives. Regulation of the form in equation (10) gives utilities the incentive to increase $\mathrm{kWh}$ sales, provided rates are greater than marginal costs; regulation of the form in equation (11) gives utilities the incentive to reduce the amount of $\mathrm{kWh}$ sales per customer.

To illustrate the use of revenue caps, in August 1994 the California Public Utilities Commission approved a five-year RCR program for San Diego Gas and Electric Company's (SDG\&E's) base rates. Under the program, O\&M costs, an important part of revenues, are allowed to increase as follows:

$$
O \& M_{n, t}=O \& \dot{M}_{n, t-1} *\left(1+1-p+G_{t}\right)
$$


where $I$ is an industry-wide input-price index, $p$ is a productivity measure, and $G$ is the growth of customers for the class of service $n .^{10}$

The discussion of inflation measures, productivity offsets, and " $Z$ " factors for price caps in the previous section apply here also. Instead of prices growing at the rate of some measure of inflation, revenues are indexed in this way. Again, pragmatic problems associated with indexing will be discussed at length in Section 3.2.

\subsection{RATE-OF-RETURN BANDWIDTH REGUIATION}

Under rate-of-return (ROR) bandwidth regulation, a utility's rates are set as they would be under COSR (see Figure 1). However, the utility's earned return on equity (ROE) for a predefined period is allowed to fluctuate in a "band" around a target or authorized return. If the earned return falls outside of the band--either above or below it-electricity rates are adjusted up or down to get the utility on track to attain the authorized return. Also, although it is not necessary, there could be some "sharing" required between a utility and its ratepayers for returns that fall outside of the band. Clearly, a utility has more incentive to cut costs if the band around the authorized return is wide.

A utility's new allowed return under ROR bandwidth regulation in the period under consideration $\left(r_{t}\right)$ can be expressed as the difference between its earned return in the prior period $\left(r_{t-1}\right)$ and an adjustment for the amount that this earned return deviates from the band around the allowed return $\left(r^{*}\right)$ :

$$
r_{t}=r_{t-1}-\lambda\left(r_{t-1}-r^{*}\right),
$$

where $\lambda$ is the sharing parameter. In this characterization of bandwidth regulation, the sharing parameter has a value of zero if the earned return falls within the band. ${ }^{11}$

An example should help understanding of this type of regulation. Suppose there is a one percentage point band around an authorized return of ten percent. Therefore, for any return that a utility earns between 9 and 11 percent, the sharing parameter in equation (13) is zero. Further assume that the utility's actual return for a given period is within the band at exactly nine percent $\left(r_{t-1}=9 \%\right)$. According to equation (13), the utility's rates for the current period $\left(r_{t}\right)$ would be lowered so that it earns a nine percent return during this period.

Suppose further that the utility shares equally with ratepayers for any return falling outside of the band $(\lambda=0.5)$ and its earned return is 12 percent $\left(r_{t-1}=12 \%\right)$. Then, from equation (13), the

\footnotetext{
${ }^{10}$ SDG\&E's fuel costs are covered under a different PBR mechenism. Also; the allowed percentage change in O\&M costs is only 65 percent of the growth rate in customers. For more details on SDG\&E's plan, see Comnes et al. (1995).

${ }^{11}$ In a limiting case, there is no band around the authorized return, $r^{\star}$. Any actual returns exceeding or falling short of the authorized return would trigger an appropriate adjustment in rates similar to the case where there is a band.
} 
utility must lower its rates in the current period so that it will earn an 11.5 percent return (i.e., $r_{t}=11.5 \%$, calculated by $\left.0.12-0.5^{*}(.12-11)\right)$. If the utility's earned return were eight percent $\left(r_{t}\right.$ $1=8 \%$ ), then it can increase its rates in the current period so that it will earn an 8.5 percent return (i.e., $r_{t}=8.5 \%$, calculated by $0.08-0.5^{\star}(0.8-0.9)$.

Alabama Power Company's (APC's) Rate Stabilization and Equalization (RSE) program is an example of ROR bandwidth regulation. Implemented in 1982, the RSE allows quarterly adjustment of Alabama Power's rates based on comparison of its earned return with a target, "adjusting point" return, currently set at 13.75 percent. If APC's actual return exceeds or falls short of the "adjusting point" by 75 basis points-i.e., greater than 14.50 percent or less than 13.00 percent--rates are automatically raised (lowered) to account for the deficiency (surplus) in earned return.

\subsection{TARGEIED INCENTIVES}

In the preceding four sections, we discussed "comprehensive" regulatory mechanisms, forms of regulation that cover the overall operation of a utility. An older and more common type of PBR mechanism is one used to target a specific aspect of a utility's operation, giving a utility incentives to improve its performance in that area.

Targeted incentives typically have three components: (1) the target of the program, (2) the standard by which performance is to be measured, and (3) the rewards and penalties for performance.

Historically, the most common target has been to improve the performance of certain electric-generating units. Troubled nuclear units have often been targeted. For example, the San Onofre and Palo Verde nuclear units owned by Southern California Edison and SDG\&E are subject to California's nuclear unit incentive procedure. In other cases, entire generating systems have been the target. For example, Delmarva Power and Light's 15 major generating units were targeted for improved performance.

Another common target has been to get utilities to invest in DSM programs. Many state commissions have encouraged utilities to invest more in these types of programs. Some states have targeted the purchase and use of fuel because the cost of fuel accounts for a large percentage of the delivered price of electricity. With the advent of more comprehensive changes in regulation such as price caps, some states have singled out customer service for special attention.

The standard of performance could be based on a utility's historical performance, the performance of a comparison group of utilities, or a standard defined by the regulator. Performance-based pricing is an example of a historical target. Pacific Gas and Electric's operation of Diablo Canyon is an example of this type of pricing. In effect, the annual price charged from Diablo Canyon is set, the plant is not put in the rate base, and the utility is allowed to recover the "purchase price" of output from the plant. In Delmarva's case, the performance 
of each of the generating units is compared individually against a predefined standard.

The reward under target regulation could be defined in terms of dollar amounts of higher (or lower) allowed revenues or as basis points for a utility's allowed ROE. For example, the fuel cost savings for the San Onofre and Palo Verde units are passed through to increase the allowable amount of revenues for the utility. United Illuminating Company was allowed to earn premium returns ranging from 100 to 300 basis points for rate-based conservation and load management programs, depending on the performance of the DSM programs.

It is not clear how effective these incentives have been in reducing costs. What is clear, however, is that singling out one area of a utility's operation for improvement at the expense of others or a utility's entire operations may not provide a proper set for incentives for the utility, resulting in sub-optimal performance. Cost reductions under these targeted programs will be discussed in greater detail in Section 4.1.

\subsection{MIXED REGULATORY APPROACHES}

Mixed approaches are combinations of two or more of the five incentive-based approaches discussed above. For example, ad hoc targeted incentives have been combined with COSR to provide incentives for utilities to improve performance in limited areas. The rate-ofreturn bandwidth regulation for Alabama Power is another example of a PBR approach combined with traditional COSR.

None of the approved and pending PBR approaches fit neatly into one of the five categories. They are mixed approaches, consisting of a comprehensive, base PBR mechanism and some targeted incentives to achieve other objectives. Targeted incentives for customer service and reliability are included in most plans, and appended to a more comprehensive regulatory form such as PCR or RCR.

Under "pure" PCR or RCR, a utility's rates could be initially set on the basis of a cost-ofservice study, and then not re-visited by regulators for a predetermined period of time (e.g., five years). Unexpected increases in inflation or the price of an important input such as fuel beyond the control of a utility's management could threaten the utility's financial viability if the price or revenue caps were not allowed to exceed the rate of growth dictated by the price index. On the other hand, a utility that was very inefficient before the imposition of price caps could earn heretofore unheard-of returns in a regulatory system in which profits are reviewed only every five years. Either situation is not likely to be politically acceptable. ${ }^{12}$

To avoid this possibility, a common practice is to combine the price (or revenue) caps

\footnotetext{
${ }^{12}$ To overcome this problem, initial prices for caps could be set at levels lower than would result from a cost-of-service study. A problem in this approach, of course, is to determine how much lower rates should be.
} 
from equation (8) (or equation (10)) with a form of the rate-of-return bandwidth (equation (13)). The latter is typically used as a mechanism for sharing gains and losses between a utility's shareholders and ratepayers, to prevent a utility from suffering exceedingly large losses or reaping exceedingly large windfalls. A "band" is defined around a target return beyond which the utility shares gains and losses with its ratepayers.

The sharing equation was defined above in equation (13):

$$
r_{t}=r_{t-1}-\lambda *\left(r_{t-1}-r^{*}\right)
$$

where $\lambda, r_{t}, r_{t-1}$, and $r^{*}$ are defined in the context of equation (13) above. The sharing parameter, $\lambda$, is equal to the utility's share of the difference between the earned ROR and the boundaries defined by the band around the authorized return.

The band can be either symmetrical or asymmetrical. A symmetrical band has equal values above and below the authorized return. An asymmetrical band has different values above and below the authorized return. At the extreme, a "collar" is a band defined only above or below the authorized return. These will be discussed in greater detail in Section 4.1.1.

In addition to a profit-sharing mechanism, targeted incentives are typically added on to comprehensive PBR programs in practice. Common ones are incentives (and penalties) for running DSM programs and maintaining or improving service quality. These will be discussed in greater detail in Sections 4.3 and 4.4 . 


\section{IMPLEMENTATION ISSUES}

In this section, we discuss three issues that are important in designing any type of pricecap plan: (1) the number of caps or price ceilings; (2) various inflation and productivity indices; and (3) "Z" factors for caps. We provide examples of actual practices throughout to clarify the concepts.

\subsection{NUMBER OF CAPS}

Theoretically, a utility could have as many caps as it has customers. In practice, however, this is not feasible, so groups or "baskets" of customers are created, combining individual customers into groups. The regulatory objective is to ensure that customers over which a utility has monopoly power are not grouped with those served in competitive markets. Some utilities use their existing tariffs as their "baskets." Other utilities combine customers under their existing tariffs into "baskets" of customers with similar characteristics. Some plans have caps only for individual baskets of customers. Others have a cap for the entire utility and for individual baskets.

CMP is an example of a utility under PCR that has caps only on individual baskets of customers, and those baskets are the customer classes existing before the PCR plan went into effect.

NMPC's proposed price-cap plan is an example of one in which there is a cap on total operations and one on each of 15 market baskets, grouped from its 16 tariffs. Specifically, NMPC's proposed over-all price cap takes the following form:

$$
P_{t}=P_{t-1} *(1+1-P+Z)
$$

where

$P_{t}=$ NMPC's average price of electricity in year $t$,

1 = the consumer price index for all goods, all urban consumers,

$p=$ the difference between the productivity of the entire economy and that of utilities in the Northeastern United States, and

$Z \quad=$ other cost categories beyond the control of NMPC's management, including deferred balances on three incentive plans, accumulated deferrals, and changes in external business conditions.

This utility-wide condition is supplemented by "side conditions" for 15 individual classes of service or "baskets" that NMPC developed from its rate classes:

$$
P_{n, t}=P_{n, t-1} *(1+1-p+Z+A)
$$

where

$$
\begin{aligned}
& n=1 \ldots 15 \text { are the market baskets for the } 15 \text { services offered by } \\
& \text { NMPC, }
\end{aligned}
$$


$A=$ a factor that allows NMPC the discretion to increase the index for individual classes of service up to $1 \%$ (i.e., $0 \leq A \leq 1$ ).

The derivation of the 15 market "baskets" from existing tariffs is illustrated in Figure 2. The tariffs, defined at the top of the figure (e.g, SC-1, SC-1B) are grouped into 15 "baskets" $\left(B_{1}\right.$ through $B_{15}$ ) shown at the bottom of the figure. From equation (15), each of the 15 baskets has its own price cap.

Baskets 1 through 12 reflect NMPC's residential and general service tariffs. They are grouped into baskets based on the most representative information about the electric-consuming habits of the customers comprising the tariffs and, therefore, their relative costs (i.e., grouped into small (S), medium (M), and large (L) amounts of usage and load factors). Tariffs SC-3A, SC-8, SC-10, SC-5, and SC-7 are grouped into one basket, $B_{13}$, because these are customers most likely to have competitive opportunities in the future. Tariffs SC-4 and SC-9are grouped together in basket $B_{14}$ because they receive power allocations from the New York Power Authority and are merely supplemented by power from NMPC. All customers under NMPC's PSC-13 tariff are grouped together in Basket $B_{15}$ because they are customers requiring electricity for outdoor lighting.

\subsection{MEASURING INFLATION AND PRODUCTIVITY FOR CAPS}

In Sections 2.2 and 2.3, we discussed price and revenue caps as alternatives to COSR. As part of these approaches, price indices and productivity measures are used to adjust automatically the maximum prices that a utility can charge in any one basket of its services. In this section, we discuss practical problems with measuring and using price indices and productivity measures in PBR plans.

As shown in Section 2.2, a utility theoretically can increase its ceiling prices in one of two ways:

1. It can use the electricity price increases of a comparison group of adjacent utilities, or even all U.S. utilities as a whole.

2. It could use the cost increases of inputs used by utilities to produce electricity.

Under the first approach, the price-cap $(P)$ for any service $n$ in year $t$ is as defined in equation (5) in Section 2.2:

(5) $P_{n, t}=P_{n, t-1} *(1+1)$,

or, for revenue caps, substitute Rev for $P$. Using the second approach, productivity must be accounted for. Therefore, we have the following in equation (6) from Section 2.2:

(6) $P_{n, t}=P_{n, t-1} *(1+1-p)$, 
Figure 2

Niagara Mohawk's 15 Market Baskets

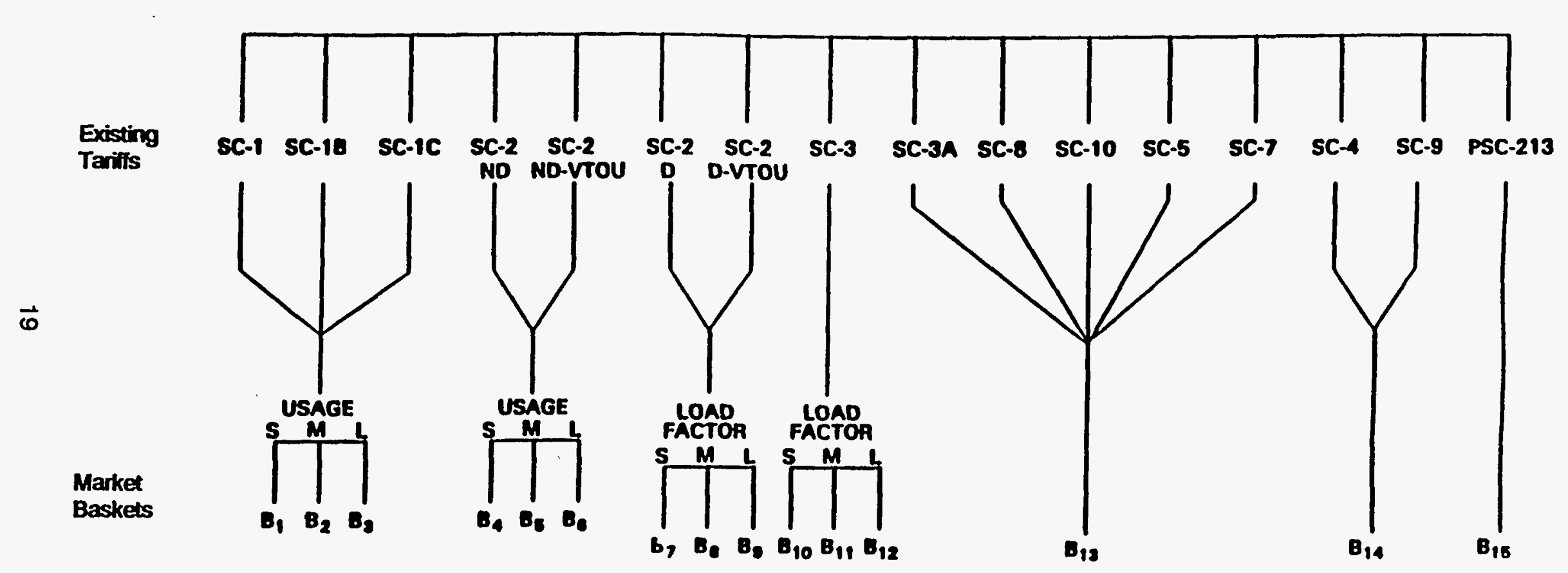

SOURCE: Adapted from Direct Testimony of R.C. Hemphill, Niagara Mohawk Power Corporation, beforo tho Now York Public Sorvice Commisaion, June 1994. 
or, again, substitute revenues for prices to obtain the relationship for RCR.

A practical problem with these two approaches is selecting the proper indices of prices, costs, or productivity to change the caps. In Table 1, we provide some possibilities of inflation and productivity measures. The base year for all indices is 1975 , and the period 1975 through 1992 was chosen because data were available for each of the indices for each of the years.

The first two indices dealing with input prices and productivity of investor-owned electric utilities are available only from private sources. ${ }^{13}$ The remaining indices are computed and published regularly by government agencies, albeit with different frequency.

If electricity output prices are to be used as the indexing mechanism, there are two possible series in Table 1:

1. series 4 , the electric power producer price index.

2. series 6 , the electricity sub-index of the consumer price index.

These series are oftentimes called "yardstick" indices because they tie the subject utility's caps to the performance of other utilities.

If electricity input prices are to be used as the indexing mechanism, there are three possibilities from the data in Table 1:

3. series (1) less series (2), an index of a utility's input prices less its estimated productivity, often called a "railroad-style" index because it is the type of index used for railroads.

4. Series (5) plus the net effect of Series (3) and Series (2), an index of the economy's retail price increases less the difference between the productivity of the entire economy and that of the electric power industry.

5. Series (7) plus the net effect of Series (3) and Series (2), an index of the economy's retail price increases less the difference between the productivity of the entire economy and that of the electric power industry.

Indices 4 and $\mathbf{5}$ are often referred to a "telephone-style" indices because they are of the type used in the PBR plans of many telephone companies.

We provide the average annual growth rates for each of these indices over three time periods at the bottom of Table 1. Using the average annual growth over the 17-year period 1975-

\footnotetext{
${ }^{13}$ See Thompson, Lowry, and Hovde (1994).
} 
Table 1

Inflation and Factor Productivity Data 1975-1992

\begin{tabular}{|c|c|c|c|c|c|c|c|}
\hline Year & $\begin{array}{r}(1) \\
\text { IOU } \\
\text { I/P Price } \\
\text { Index }\end{array}$ & $\begin{array}{r}(2) \\
\text { IOU } \\
\text { TFP } \\
\text { Index }\end{array}$ & $\begin{array}{r}(3) \\
\text { BLS } \\
\text { Multifactor } \\
\text { Productivity }\end{array}$ & $\begin{array}{r}(4) \\
\text { PPI } \\
\text { Electric } \\
\text { Power }\end{array}$ & $\begin{array}{r}(5) \\
\text { CPI } \\
\text { All Urban } \\
\text { Consumers }\end{array}$ & $\begin{array}{r}\text { CPI } \\
\text { Electricity }\end{array}$ & $\begin{array}{l}\text { GDP } \\
\text { IPD }\end{array}$ \\
\hline 1975 & 1.000 & 1.000 & 1.000 & 1.000 & 1.000 & 1.000 & 1.000 \\
\hline 1976 & 1.082 & 1.021 & 1.043 & 1.074 & 1.058 & 1.062 & 1.063 \\
\hline 1977 & 1.170 & 1.022 & 1.062 & 1.204 & 1.126 & 1.132 & 1.136 \\
\hline 1978 & 1.305 & 1.010 & 1.078 & 1.294 & 1.212 & 1.218 & 1.226 \\
\hline 1979 & 1.614 & 1.024 & 1.072 & 1.397 & 1.35 & 1.312 & 1.331 \\
\hline 1980 & 2.130 & 1.018 & 1.056 & 1.662 & 1.532 & 1.516 & 1.457 \\
\hline 1981 & 2.522 & 1.018 & 1.069 & 1.897 & 1.690 & 1.744 & 1.604 \\
\hline 1982 & 2.728 & 1.007 & 1.084 & 2.101 & 1.794 & 1.916 & 1.703 \\
\hline 1983 & 2.712 & 1.032 & 1.112 & 2.160 & 1.851 & 1.978 & 1.772 \\
\hline 1984 & 3.027 & 1.054 & 1.146 & 2.273 & 1.931 & 2.106 & 1.850 \\
\hline 1985 & 3.068 & 1.049 & 1.158 & 2.345 & 2.000 & 2.178 & 1.919 \\
\hline 1986 & 2.883 & 1.025 & 1.173 & 2.366 & 2.037 & 2.208 & 1.970 \\
\hline 1987 & 3.053 & 1.045 & 1.217 & 2.324 & 2.112 & 2.200 & 2.033 \\
\hline 1988 & 3.039 & 1.044 & 1.235 & 2.336 & 2.199 & 2.230 & 2.112 \\
\hline 1989 & 3.110 & 1.056 & 1.229 & 2.412 & 2.305 & 2.294 & 2.205 \\
\hline 1990 & 3.198 & 1.067 & 1.207 & 2.471 & 2.429 & 2.348 & 2.303 \\
\hline 1991 & 3.175 & 1.066 & 1.204 & 2.611 & 2.532 & 2.436 & 2.392 \\
\hline 1992 & 3.175 & 1.051 & 1.246 & 2.653 & 2.608 & 2.484 & 2.461 \\
\hline \multicolumn{8}{|l|}{ \% Growth: } \\
\hline $1975-92$ & $6.8 \%$ & $0.3 \%$ & $1.3 \%$ & $5.7 \%$ & $5.6 \%$ & $5.4 \%$ & $5.3 \%$ \\
\hline $1987-92$ & $0.8 \%$ & $0.1 \%$ & $0.5 \%$ & $2.6 \%$ & $4.2 \%$ & $2.4 \%$ & $3.8 \%$ \\
\hline $1982-92$ & $1.5 \%$ & $0.4 \%$ & $1.4 \%$ & $2.3 \%$ & $3.7 \%$ & $2.6 \%$ & $3.7 \%$ \\
\hline
\end{tabular}

(1) Input-price index for IOUs (Thompson, Lowry, and Hovde, 1994)

(2) Total factor productivity for lOUs (Thompson, Lowry, and Hovde, 1994)

(3) Multifactor productivity index for U.S. private business (Bureau of Labor Statistics)

(4) Producer price index-electric power (Bureau of Labor Statistics)

(5) Consumer price index-all urban consumers-all goods (Bureau of Economic Analysis)

(6) Consumer price index-electricity subindex (Bureau of Economic Analysis)

(7) Gross domestic product, implicit price deflator (Bureau of Economic Analysis) 
1992, the five indexing possibilities have the average annual growth rates over the period 19751992 contained in Table 2.

The results in Table 2 suggest that the financial condition of a utility and the effect on its customers could vary dramatically depending on the type of index used to change ceiling prices from period to period. ${ }^{14}$

Table 2

Differences in Ceiling Growth Rates

5 Indexing Approaches

Approach

Calculation $^{\mathrm{a}}$

Average

Annual

Growth $^{b}$

Yardstick

Producer Price Index-Electricity

Consumer Price Index-Electricity

Series (4)

$5.7 \%$

Series (6)

$5.4 \%$

Railroad Style

Utility Input Costs

Series (1)-(2)

$6.5 \%$

Telephone Style

Consumer Price Index-All Goods

Gross Domestic Product-Implicit Price Deflator

Series $(5)+((3)-(2))$

$6.6 \%$

Series $(7)+((3)-(2))$

$6.3 \%$

${ }^{a}$ Refers to the numbered series in Table 1.

${ }^{b}$ Average annual growth rate in ceiling prices over the 17-year period from 1975-1992.

\section{3. "Z" FACTORS FOR CAPS}

A "Z" factor is a pass-through of certain costs to customers in a price- or revenue-cap plan. It adjusts the growth rate of prices for any class of service or basket of goods for reasons other than changes in inflation and productivity. For example, if the index-adjusted price ceiling for a basket of goods were 10\%/kWh based on revenues of $\$ 1$ million and sales of 10 million $\mathrm{kWh}$, the price would increase to $11 \mathrm{c} / \mathrm{kWh}$ if $\$ 100,000$ were passed through to ratepayers in this basket as a "Z" factor. Used in this way, "Z" factors move utilities closer to a cost-plus regulatory

\footnotetext{
${ }^{14}$ To estimate the effects of using different price indices and measures of productivity on the financial condition of electric utilities, we simulated their use on a hypothetical utility using the Oak Ridge Financial Model (ORFIN), a financial regulatory simulation model developed at Oak Ridge National Laboratory. For further details, see Hill (1995).
} 
model than a competitive one.

There are many different types of " $Z$ " factors. They can include any revenues or expenditures of a utility other than targeted incentives such as those used for running DSM programs, improving service quality, and the like. An example of a "Z" factor is "regulatory assets" under Statement of Financial Accounting Standards No. 71 that arose when a utility was regulated on a cost-plus basis and is entitled to collect when changing to a different regulatory model. The costs were allowed to be deferred when they occurred under the assumption that they would be recouped in later years under COSR.

"Z" factors can be used for any other "special provision" that regulators and utilities devise, other than special costs arising from utility accounting. One example is CMP's lowincome life-line pricing program, included as a "Z" factor.in CMP's Alternative Rate Plan.

Other PBR plans include changes in energy costs as "Z" factors. NMPC, for example, proposes an energy cost adjustment mechanism (ECAM) under its PBR proposal to replace its fuel adjustment clause (FAC) created under COSR. Under the ECAM, NMPC proposes a sharing mechanism-up to a point--between customers and shareholders for the difference between indexed energy costs for retail customers and the actual energy costs paid by retail customers.

Indexed energy costs, referred to as indexed net energy revenue (NER), is in reality a sub-index of fuel costs for NMPC's total price index (i.e., the CAPNDX). Forecasted unit energy costs for retail customers are changed annually based on CAPNDX, the same index used to cap NMPC's 15 baskets. The energy costs paid by retail customers are referred to as net energy costs (NEC) under ECAM. NEC is the total cost of energy less revenues from sales for resale.

The values of NER and NEC are compared annually. Differences up to $\$ 50$ million between NER and NEC are split 60/40 between customers and shareholders, respectively. Any amount greater than $\$ 50$ million is paid totally by customers with increases in their rates using a "Z" factor as the mechanism.

The reason for this energy-cost " $Z$ " factor is that the consumer price index used to reflect changes in the quarterly caps for NMPC's 15 baskets may not respond quickly to changes in external energy markets. Because energy costs are such a large portion of NMPC's total costs, ECAM was proposed as part of NMPC's PBR plan.

Although some pending and approved PBR plans have targeted incentives for DSM programs built in, others treat some types of DSM programs as a "Z" factor. For example, New York State Electric and Gas (NYSEG) must run an Affordable Energy Program that provides education, weatherization, energy packaging, and financial assistance to 2,500 low-income, residential customers. The $\$ 475,000$ total cost of the program will be allocated to the rates of residential customers. 
NYSEG's R\&D expenditures could also be included as a "Z" factor. The utility budgeted $\$ 11,498,000, \$ 11,235,000$, and $\$ 9,029,000$ for $R \& D$ expenditures in the first three years of its PBR plan. If NYSEG must increase its R\&D expenditures for the three years, they will be flowedthrough dollar-for-dollar into rates. 


\section{ELECTRIC UTILTYY INCENTIVES UNDER PBR}

All forms of economic regulation provide incentives to utilities. The challenge for regulators is to develop a regulatory approach with the type of incentives that maximizes society's objectives.

As discussed in Section 1, COSR as historically practiced by electric utilities has been criticized by both regulatory theorists and practitioners because it does not provide incentives to lower costs. However, because electric utilities are allowed to recover all of their prudently incurred costs under COSR, they have more of an incentive to improve service quality. Therefore, a trade-off exists between cost reduction and the quality of electric service under COSR.

All of the other regulatory forms discussed in this primer provide incentives to varying degrees to accomplish some objective(s), either targeted (e.g., run DSM programs) or more general for the utility (e.g., reduce costs more than under COSR).

In this section, we examine the incentives provided electric utilities under economic regulation to accomplish three objectives: (1) to lower costs, (2) to price efficiently, (3) to promote energy efficiency, and (4) to improve service quality. Because regulatory models such as PCR and RCR are relatively new in the electric power industry, there is very little empirical evidence on the behavior of electric utilities in response to these models. The design of these regulatory models, however, can tell us much about the type of behavior they are likely to induce.

\subsection{TO LOWER THE COST OF PRODUCING ELECTRICTTY}

There is a distinction between incentives (1) to reduce the short-run costs of producing electricity such as adopting measures to reduce excessive labor costs and (2) to reduce long-run costs by innovating and investing in technologies that will reduce the cost of producing electricity in the long run. The distinction between the two is expenditures on plant and equipment. In the short run, we are talking about improving the efficiency of using labor, energy, and materials, given investment in plant and equipment. In the long run, investments in more efficient capital stock will also reduce the cost of producing electricity. The discussion here addresses both time frames; the distinction between the two should be obvious from the context of the discussion.

Many of the targeted PBR programs discussed in Section 2.5 address the short-run cost concerns of regulators. The best example is providing electric utilities the incentive to improve the efficiency of troubled electric-generating units. For this target, there is sufficient experience to see what effect the incentive has on cost reduction.

For example, a study of targeted incentive programs for electric utilities over the 1973- 
1985 period $^{15}$ concluded that, although these programs improved engineering efficiency (i.e., the heat rates of the plants), they were ineffective in improving economic efficiency. The savings were small, and the authors argued that more general forms of PBR such as price caps offered more promise for improving a utility's economic efficiency.

Similar studies of more comprehensive PBR approaches are limited to industries other than the electric power industry, such as the behavior of telecommunications firms in response to the introduction of PBR. One study ${ }^{16}$ indicates that PCR in the telecommunications industry leads to lower rates. States that allow pricing flexibility under PCR have significantly lower rates than states that continue to use COSR.

However, the experiences of the telecommunications and electric power industries are not necessarily the same. Important differences exist in the cost structures of electric utilities in comparison with telecommunications firms. For example, the electric industry is more capital intensive than the telecommunications industry, requiring larger amounts of investment per unit of output. And, investments in the electric industry tend to be more "lumpy" than those in telecommunications, requiring significant amounts of capital expenditures in discrete periods.

A convenient way to characterize the design features of various forms of regulation is to isolate the degree to which they provide incentives for utilities to lower costs: ${ }^{17}$

(16) Revenues $=a+b$ * costs,

where "a" is fixed and "b" varies from 0 to 1 . At one extreme where $b=0$, the electric utility has the most incentive to reduce costs. In economic theory, this is the case of a perfectly competitive firm. The firm is a "price taker," the price determined in a competitive market. The firm earns revenues in the amount of "a" from equation (16), depending on the amount of output it sells in the market. At the other extreme where $b=1$, the utility recovers all of its costs by setting rates that cover these costs. This is the case of a utility subject to "pure" cost-of-service regulation. Prudently incurred costs are allowed in revenues and the design of a utility's tariffs.

In Figure 3, we characterize incentives in this way to examine three important design features of PCR, RCR, and COSR. The spectrum at the top varies from a regulated monopoly under $\operatorname{COSR}$ where $b=1$ at the left to a perfectly competitive firm in economic theory where $b=0$ at the right. Below this spectrum, we show the extremes of three design features of comprehensive PBR: (1) profit sharing, (2) time between rate cases (or regulatory lag), and (3) the level of price caps.

\footnotetext{
${ }^{15}$ Berg and Jeong (1991, 1994).

${ }^{16}$ The study was conducted by Mathios and Rogers (1989).

${ }^{17}$ This characterization was introduced by Laffont and Tirole (1993).
} 


\section{Figure 3}

Incentives to Reduce Costs Under Economic Regulation

\section{Revenues $=\mathrm{a}+\mathrm{b} *$ Costs}

$b=1$

(Low-Powered Incentives)<smiles>C1CCCCC1</smiles>

Regulated

Monopoly $\mathrm{b}=0$

(High-Powered Incentives)<smiles>C=C</smiles>

Perfectly Competitive

Firm

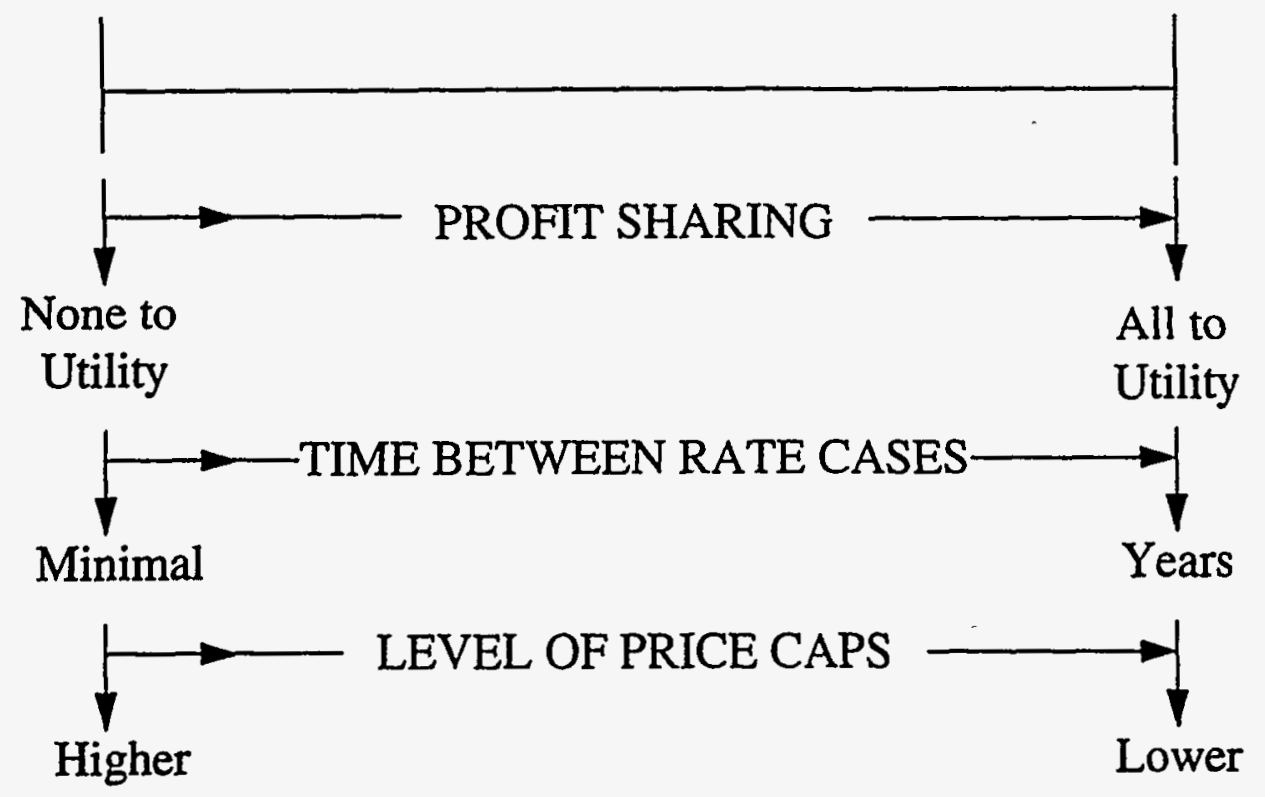

\subsubsection{Profit Sharing}

Profit-sharing refers to a utility sharing earnings with its ratepayers. It is usually expressed in terms of percentage ROE, and is usually defined in terms of a "band" around a target return. For ratepayers, profit-sharing means higher prices if a utility does not meet its target return, and lower prices if it exceeds its target. For stockholders, profit-sharing means higher earnings if the utility exceeds its target. The reverse is true when it falls short.

As discussed in Section 2, "pure" price or revenue caps may not be politically acceptable to regulators, intervenors, and the general public. The reason is that a utility may earn profits 
that cannot be justified to its constituency, necessitating a "re-contracting" process on the part of regulators and the utility.

The British experience with PCR for their 12 regional electric distribution companies (RECs) illustrates how political opposition to the PBR process can emerge in the face of high utility profits. Without profit sharing between the RECs and its customers during the first five-year period of PCR ending on March 31, 1995, the RECs performed well, generally earning returns in the range of 20 percent. In determining new caps for the next five years of the plan, ratepayers initially were not given as much of the productivity gains as the public expected. At this point, the political viability of PCR for RECs in Britain is threatened.

From Figure 3, there is a trade-off between the percenage of profits that a utility is allowed to keep and its incentives to reduce costs. At one extreme, a utility is not allowed to keep any earnings in excess of its target. "Pure" cost-of-service regulation-with no regulatory lag-is an example of a sharing mechanism in which customers get all excess profits. At the other extreme, the utility gets all of the profits. That is, there is no sharing mechanism. This is the case of a "pure" PCR or RCR approach.

In practice, some mechanism is usually built into a PBR process to ensure that the utility does not earn excess profits, to share excess savings or losses, and to trigger a new rate case if returns are exceedingly high or low. In fact, it has been argued that profit-sharing between a utility's shareholders and customers should be preferred by electric utilities because it results in higher profits for the utility in the long run. ${ }^{18}$ The reason is that profit-sharing dampens the incentives of regulators to take actions that could result in reducing the profits of the utility.

The challenge for policymakers is to design an optimal sharing mechanism, balancing the interests of shareholders, ratepayers, and the regulatory responsibility to protect the interests of both parties and the public. One study showed that this optimal sharing fraction varies widely, depending on the firm's potential for cost reduction, the magnitude of potential cost shocks, the level of uncertainty about the ability of utilities to reduce costs, the regulator's objectives, and the price elasticity of demand for electricity. ${ }^{19}$

In most pending and approved PBR plans, a "band" defined in terms of basis points (i.e., ROE) is placed around a target ROE as defined by equation (13) above and repeated here:

(13) $r_{t}=r_{t-1}-\lambda^{*} \cdot\left(r_{t-1}-r^{*}\right)$,

where $r_{t}$ is the ROE in year $t, r^{*}$ is the target return, and $\lambda$ is the sharing parameter.

${ }^{18}$ See Dennis L: Weisman (1994) for a more detailed explanation of this argument.

${ }^{19}$ See Schmalensee (1989) for further details. 
CMP's band around a target ROE is an example of a symmetrical one. A band is placed around CMP's targted equity return of 10.55 percent. Earnings in excess of the target but less than or equal to 14.05 percent--a 3.5 percent upper band-are kept by CMP's shareholders. Earnings greater than 14.05 percent are shared equally by CMP's shareholders and ratepayers. Similarly, earnings 350 basis points below the 10.55 percent target are borne exclusively by CMP's shareholders. Earnings more than 350 basis points below the target are shared equally by shareholders and customers.

Earnings outside the lower band can also result in proceedings to terminate the PBR program. On the initiative of CMP, the plan can be terminated if CMP's actual ROE falls outside the sharing mechanism band for two consecutive years. ${ }^{20}$

There are also PBR plans with asymmeirical bands around a target ROE. For example, NMPC proposes an asymetrical "collar" around its 11 percent target ROE. There are three possibilities:

- Earnings in excess of 11 percent are placed in a special deferred account. This account can be used for an accelerated draw-down of regulatory assets or, as discussed below, to offset returns less than eight percent.

- Earnings less than or equal to 11 percent but greater than or equal to eight percent are absorbed by NMPC's shareholders.

- At any point in time, if earnings are less than eight percent for twelve trailing months or the forecasted twelve months, NMPC can offset the deficiency with any deferred credits earned in prior periods, or call for a rate case. The rate case is at NMPC's discretion and effectively ends the price-cap plan. NMPC can also file for a rate case if its first mortgage bonds are rated below "BBB" by Standard and Poors or "Ba3" by Moodys. Again, the rate filing is at NMPC's discretion.

SDG\&E's profit-sharing arrangement is another example of an asymmetrical approach. Any ROR down to 150 basis points below the authorized return is absorbed by SDG\&E's shareholders. SDG\&E can request a suspension of the PCR plan for returns in excess of 150 basis points below the authorized amount. Returns up to 100 basis points greater than the authorized amount go entirely to SDG\&E's shareholders. Returns between 100 and 300 basis points greater are shared equally by ratepayers and shareholders. Returns greater than 300 basis points of the target trigger an automatic suspension of the mechanism with a Commission review that may include a rate case.

\footnotetext{
${ }^{20}$ There is a second way in which CMP's plan can be terminated. At any interested party's initiative, the plan can be terminated if CMP does not achieve 90 percent of its DSM target adopted in its Energy Resource Plan for two consecutive years.
} 


\subsubsection{Time Between Rate Cases}

Figure 3 also shows that the time interval between rate reviews affects a firm's incentives to reduce costs. The shorter the time interval, the less likely that a firm will take measures to reduce its short- or long-term costs. The longer the interval, the more likely that a firm will reduce costs because it has the possibility of earning more profits.

This pertains to COSR as well as PCR and RCR. Under PCR and RCR, the length between reviews is important because, like COSR, rates of a utility could be ajusted to costs after a review period.

Indeed, COSR may provide more incentives for a utility to reduce costs than either PCR or RCR if the period between regulatory review (i.e., regulatory lag) is long and institutionalized as part of the regulatory process. In terms of Figure 3, COSR with a four to six year institutionalized lag, for example, may provide a utility more incentives to reduce costs than a PCR or RCR plan with a shorter time between regulatory reviews, say every two years.

There is some limited empirical evidence to support the cost-reducing benefits of institutionalized lag. One example is Tucson Electric Power Company (TEPCO) in the 1980s. ${ }^{21}$ In November 1983, TEPCO and the Arizona Corporation Commission (ACC) agreed that, in return for some concessions by ACC, TEPCO would not ask for a general rate increase before January 1987, subsequently amended to August 1987. During that period of time, TEPCO cut its costs and was able to earn equity returns exceeding 17 percent, well above historical levels.

\subsubsection{Level of Price Caps}

As discussed above, utilities initially set cost-based rates in a base year and adjust the ceilings on rates quarterly or annually using some inflation index under PCR or RCR. The index could reflect output market prices or input costs. In the latter case, the cost index must be adjusted for productivity changes.

In Figure 3, we show that, the lower the level of prices under PCR or RCR, the more incentive utilities have to reduce costs. This is true to a point. At some threshold level of prices, the utility's incentive to invest in measures to reduce costs is eliminated. Therefore, the incentive for utilities to reduce cost is not a continuous function of the price level. ${ }^{22}$

The relationship between the price level under PCR and the incentive for a utility to lower costs is one reason why regulators may want to use the productivity variable as a "stretch" factor in PCR. That is, by setting the productivity value at a level higher than would be justified by historical experience in the price-cap equation,

\footnotetext{
${ }^{21}$ Interested readers will find a good account of the TEPCO experience in Issac (1991).

${ }^{22}$ This conclusion is attributable to Cabral and Riordan (1989) in their comparison of PCR and COSR.
} 
(6) $P_{t}=P_{t-1} *(1+1-P)$,

the annual change in the price cap would be less than if the productivity offset were set at historical levels. Lower annual price levels result and, therefore, greater incentives for utilities to lower costs. ${ }^{23}$

\subsection{TO PRICE EFFICIENTLY}

Under pure COSR, prices are set. These prices are both ceilings and floors. A utility must incorporate them as part of its tariffs for various customer classes. Under comprehensive PBR approaches such as PCR and RCR, maximum prices and maximum revenues are set, respectively, indexed to account for inflation. The prices and revenues are ceilings under which utilities are given flexibility to price to respond to and meet prices charged by competitors.

In practice, the type and degree of pricing flexibility given utilities varies from plan to plan. In CMP's five year price-cap plan, for example, the Maine Public Utility Commission defines rigid boundaries for CMP's pricing behavior. CMP must meet certain criteria for setting rates for three service categories without MPUC approval: (1) existing customer classes, (2) new customer classes for optional targeted services, and (3) special rate contracts. CMP can set rates that do not meet the criteria, but they require MPUC approval.

For existing customer classes, CMP can set rates between the price cap and long-run marginal cost as long as LRMC is not more than 40 percent below the cap. If LRMC is more than 40 percent below, the floor is 60 percent of the price cap. In addition to price changes caused by the annual change in the price cap, CMP cannot make more than two price changes per year. For new customer classes that CMP develops, the applicable price cap is the one closest to that the customers would fall under if they were an existing customer. For special contracts with individual customers, CMP can enter into short-term contracts with five years or less that begin in either 1995 or 1996, with a discount from the cap. Over the life of the contract, the revenue collected cannot be lower than CMP's short-run marginal cost plus 1.5 cents per $\mathrm{kWh}$. CMP can also enter into long-term contracts, but they must be approved by MPUC.

Niagara Mohawk, on the other hand, proposed an " $A$ " factor to give itself revenue-shifting flexibility in its pricing. An "A" factor is included for each of NMPC's proposed 15 service baskets. The factor gives NMPC the flexibility to reallocate revenue among different baskets of services, depending on its pricing practices. That is, if NMPC lowers prices below the ceiling for one of the 15 baskets, it can recoup the lost revenue--at least in part--by increasing the indexed cap for other customer classes by increasing the " $A$ " factor. The maximum that the price index can increase in any one year for any class of service--i.e., the maximum value of $A$-is one percent.

\footnotetext{
${ }^{23}$ Another reason for using a productivity offset factor greater than historical amounts is if cost-ofservice regulation resulted in inefficiencies and, hence, productivity levels lower than what would have been attained if they were not subject to COSR.
} 
NMPC's PCR plan is a proposal and CMP's Alternative Rate Plan began on January 1, 1995. Other approved PCR and RCR plans are as new as NMPC's and CMP's. Therefore, there is no empirical evidence to see how utilities subject to PCR and RCR will set prices for their customer groups-i.e., how far below the caps prices are set for different customer groups.

Economic theory suggests that the degree of competition, price elasticities of demand for electricity by a utility's customer classes, and conditions in the general economy will play a role in determining how utilities will set prices. Also, elimination of the need for a utility to allocate fixed costs to various customer classes when setting rates is an important consideration in pricing under PCR. If a utility is not required to allocate fixed costs to its customer classes when setting rates and is given sufficient pricing flexibility, it will eventually lead the utility to "Ramsey pricing," where the price for service $n$ is given by: ${ }^{24}$

$$
\left(P_{n}-M C_{n}\right) / P_{n} \quad=(\delta / 1+\delta)\left(1 / \epsilon_{n}\right)
$$

where $M C$ is the marginal cost of producing $n$ and $\epsilon_{n}$ is the own-price elasticity of demand for commodity n. Equation (17) defines the inverse elasticity rule for efficient pricing. The percentage deviation of price from marginal cost for any commodity $n$ is inversely proportional to the own-price elasticity of demand for that commodity. Or, in other words, the greater the elasticity of demand for electricity, the lower the price will be. ${ }^{25}$

The inverse elasticity rule--or Ramsey pricing--is a second-best pricing solution. Marginal cost pricing is the first-best solution for allocating resources in an economy. However, where market distortions such as the existence of taxes and monopolies exist, the first-best solution is often unattainable. This is the case with electric utilities because they are regulated as natural monopolies.

If a utility under PCR or RCR must submit to a periodic rate review and prices during this review are re-adjusted to reflect allocated costs, the tendency of utilities to use Ramsey prices will dwindle, and the efficiency benefits of Ramsey pricing will not be realized.

\subsection{TO PROMOTE ENERGY EFFICIENCY}

Many state policies toward electric utilities were made in an environment in which utilities were franchise monopolies. Integrated resource planning (IRP) is one such policy. IRP is a planning paradigm used by investor-owned utilities in more than 30 states. Although it is implemented differently across utilities and states, in its most basic form IRP is a management

${ }^{24}$ See Baumol and Bradford (1970).

${ }^{25}$ Ramsey prices are second-best economically efficient prices. There may also be equity considerations. For example, to the extent that certain customer groups have lower elasticities of demand such as low-income customers, the higher their rates will be. This may not be acceptable to policymakers. 
tool that requires electric utilities to compare consistently the cost-effectiveness of all their resource alternatives--those on both the demand and supply side--taking into account the different economic and reliability characteristics of these alternatives.

Although the Energy Policy Act of 1992 encourages the adoption of IRP by state commissions, it also creates the framework for a more competitive electric power industry. Many state regulators and legislators are now considering the future of IRP in their states.

Also, electricity prices will increasingly be set in markets. The guiding economic principle for investments in market-based economies is this: Do the revenues of the investment exceed its costs? If not, the investment is not made. The principle applies to investments in electricgenerating units as well as those in DSM programs.

A problem is that IRP is used as an umbrella for implementing public policy objectives such as running DSM programs, adopting renewable energy forms, and promoting environmental quality. Many of these programs may not be cost-effective in the emerging competitive marketplace. As the avoided cost of power decreases in a competitive market, the less attractive. these programs become to electric utilities on an economic basis. And, the more that expenditures on cost-ineffective programs are flowed through to ratepayers, the more PBR becomes like COSR.

Recognizing a competitive market's negative effect on the adoption of DSM programs by electric utilities, regulators have made the running of these programs targeted incentives in PCR and RCR models.

The MPUC, for example, penalizes CMP for not attaining DSM savings goals defined in their annually updated Electric Resource Plan. On the up-side, if CMP saves more than its target in any given year, a $\$ 1.0$ million deferred credit will be created to offset penalties that it would incur if it does not attain its DSM goals in other periods. The targeted DSM savings for 1995 are $45 \mathrm{GWh}$. CMP is considered to have attained that target if it achieves at least 90 percent of it. If it falls short of its goals, the following penalties apply:

$\begin{array}{ll}\text { Savings } & \text { Reduction in Revenues } \\ 85-89 \% & \$ 1.5 \text { million } \\ 80-84 \% & \$ 2.0 \text { million } \\ 75-79 \% & \$ 3.0 \text { million } \\ <75 \% & \$ 5.0 \text { million }\end{array}$

The other pending and approved PBR proposals for electric utilities also target DSM programs in some way. They include the plans of Niagara Mohawk, San Diego Gas and Electric, Southern California Edison, Pacific Gas and Electric, and PacifiCorp's California operations. 


\subsection{TO IMPROVE SERVICE QUALTY}

Under traditional COSR, utilities do not have incentives to reduce service quality. If costs are passed through dollar-for-dollar in rates as they are under traditional COSR, utilities have the incentive to maintain or improve their quality of service.

This may not be the case under comprehensive PBR regulation models. Because costs are not necessarily reflected in rates under these schemes, there may be a tendency for utilities to cut costs at the expense of customers' quality of service. To eliminate that possibility, all of the approved and pending comprehensive PBR plans have built in a targeted incentive for utilities to maintain or improve service quality.

For example, in its price-cap proposal, Niagara Mohawk can lose as much as \$6 million annually, based on attaining or missing seven service and reliability targets:

$\begin{array}{ll}\begin{array}{l}\text { Missed } \\ \text { Targets }\end{array} & \text { Penalty } \\ 0-2 & \$ 0 \text { million } \\ 3 & \$ 2 \text { million } \\ 4 & \$ 4 \text { million } \\ 5-7 & \$ 6 \text { million }\end{array}$

CMP also has a customer service and reliability incentive, the Customer Service and Reliability Index, based on five measures of performance: two for customer satisfaction determined on the basis of phone surveys; two for service reliability, including the duration of interruptions (base equals 180 minutes) and the average number of interruptions (two excluding those for storms); and one for customer service.

Each indicator is worth 20 points for a total of 100 . Sub-par performance for any of the indicators reduces the indicator on a percentage basis (i.e., the percentage short-fall times 20 points). If CMP meets or exceeds the indicator, it receives 20 points. The penalty for a performance less than the indicator is as follows:

$\begin{array}{ll}\text { Points } & \text { Penalty } \\ 99-99.9 & \$ .25 \text { million } \\ 98-98.9 & \$ .50 \text { million } \\ 97-97.9 & \$ .75 \text { million } \\ 96-96.9 & \$ 1.0 \text { million } \\ 94-95.9 & \$ 1.5 \text { million } \\ 92-93.9 & \$ 2.0 \text { million } \\ <92 & \$ 3.0 \text { million }\end{array}$




\section{CONSISTENCY WITH FINANCIAL ACCOUNTING STANDARDS}

A problem with economic regulation as it has historically been applied to electric utilities is that prices reflect prudently incurred costs. Therefore, utilities have little incentive to lower their costs. PBR, by giving utilities flexibility in pricing and investment decisions, severs the cost-price relationship.

In severing that relationship, however, policymakers must keep in mind the existence of "regulatory assets," items of expenditure that are capitalized-instead of charged to current operations-and amortized over multiple years. The Edison Electric Institute estimates that investor-owned electric utilities currently have more than $\$ 75$ billion of regulatory assets on their books.

The Financial Accounting Standards Board gave regulators and utilities the ability to create "regulatory assets" in Statement of Financial Accounting Standard No. 71, "Accounting for the Effects of Certain Types of Regulation." To take advantage of this accounting standard, several conditions must be met. First, an independent regulator or board must review the rates of the utility capitalizing the expenses. Second, and most important, a utility's rates must be set to recover its costs of service.

In severing the price-cost relationship, a utility with regulatory assets in its financial accounting records must take into consideration whether a proposed PBR plan violates the criteria set forth in SFAS-71. In justifying its PCR proposal, Niagara Mohawk, for example, argued that its plan did not violate the accounting standard because it plans to use a cost index rather than a price index in changing price ceilings from period to period. Also, in its ROE "band" proposal, NMPC can file for a new rate case if earnings fall below a prespecified threshold, further ensuring that rates track costs.

The CMP plan went even further. Its October 14, 1994 Stipulation creating an Alternative Rate Plan stated in part: ${ }^{26}$

The Alternative Rate plan is not deregulation either from a ratemaking or an accounting perspective. The Company will continue to be subject to Generally Accepted Accounting Principles because the rates under the Alternative Rate Plan are intended to meet the criteria of SFAS No. 71 paragraph 5. In particular, the accounting standards which specifically apply to regulated industries, were considered in designing the Alternative Rate Plan.

\footnotetext{
${ }^{26}$ Central Maine Power Company (1994).
} 



\section{CONCLUSION}

At the top of Figure 4, we show a range of public policy approaches toward electric utilities, using the degree of entry into electricity markets as the organizing metric. At one extreme, electric utilities could be left unregulated. At the other, they could participate in competitive markets.

Figure 4

Market Stages for Electric Utilities

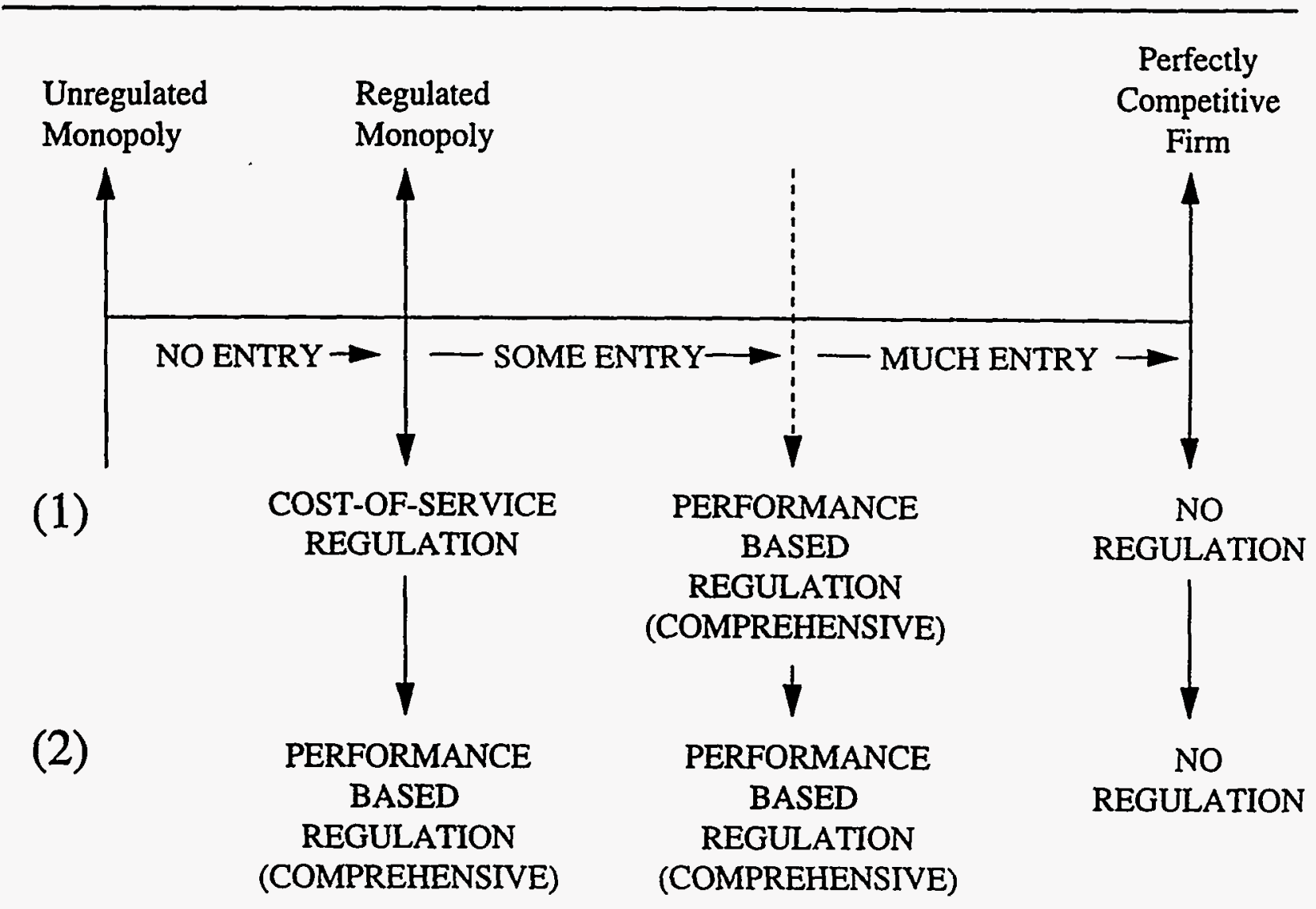

Because electric utilities have natural monopoly characteristics, leaving them unregulated has not been historically considered. Utilities have been regulated as natural monopolies because of the economies associated with building large power plants and those associated with being vertically integrated. Recently, advances in electric-generating technology allow scale economies to be exploited with much smaller plant sizes. Consistent with these technological changes, federal legislation and policy initiatives by the Federal Energy Regulatory Commission 
promote more competitive electric-generating markets. The objective of these federal initiatives is to increase the efficiency of electric power production, thereby reducing costs and electricity prices. In terms of Figure 4, federal initiatives promote more entry of non-utility firms into electricity markets, competing with heretofore franchise monopolies.

The degree of competition in electricity markets, however, will not be uniform across the country. Despite the federal initiatives, state policymakers have a lot of discretion to shape their electric power markets. In some areas of the country, electric utilities have been facing competition for years, and state policymakers have taken actions to allow utilities to better compete in the emerging competitive marketplace. In other parts of the country, utilities face very little competition, and are not likely to face much more in the future.

The speed at which markets become competitive will also vary. Again, policymaking at the state level will determine the speed of the transition from a regulated-monopoly market to a competitive one.

For policymakers in states where utilities are facing--or will soon face--competition, two time frames must be considered. First, there is the transitional phase from a regulated-monopoly electricity market to a competitive one. By severing the relationship between costs and prices and providing more pricing flexibility, PBR is one way that regulators can give utilities the ability to compete. In Scenario (1) of Figure 4, we show this case. PBR is a step across the spectrum from COSR. At some point when entry into the industry is sufficiently free that electric utilities will suffer financially if they cannot compete with new entrants on an equal basis, PBR should be introduced.

Many would argue that PBR should be introduced even in regulated-monopoly electricity markets (Scenario 2 in Figure 4). Recalling the discussion in Section 1.2, COSR regulation does not generally provide incentives for utilities to reduce costs or innovate. PBR is viewed as a mechanism to substitute for COSR and eliminate these distorted incentives.

The second important time frame for policymakers is at a point in time when regulation is no longer needed because markets are competitive. In a competitive market, there are no barriers to exit and entry. Firms have the incentive to lower costs and become more efficient because lower costs translate into higher profits--at least in the short run. In the long run, firms have the incentive to innovate, lower costs, and thereby gain a competitive advantage over their rivals. Competitive firms can immediately raise or lower their prices consistent with market conditions. Regulation is replaced by the market.

However, only the generating portion of the industry will be competitive in most electricity markets. Regulation will still be required for residual natural monopolies: the transmission and distribution functions. The challenge for regulators at this point in time is to develop a regulatory model that accomodates the specific features of the "wires" portion of the industry. Is PBR the proper approach for transmission and distribution only? If so, how must PBR be adapted to meet 
the special circumstances of transmission and distribution? If not, will COSR provide the proper incentives to reduce costs?

In both of these time frames, there is another important challenge for policymakers if PBR is selected as the regulatory model: ensuring that PBR does not converge to COSR. As we showed, the major difference between COSR and comprehensive PBR approaches such as PCR and RCR is the relationship between prices and costs. Under "pure" COSR in which there is no regulatory lag, there is a dollar-for-dollar correspondence between costs and prices. Higher costs are "flowed through" to ratepayers in the form of higher rates. Under "pure" PBR approaches such as PCR and RCR, there is not necessarily a dollar-for-dollar correspondence between costs and prices--at least in the short term. There are incentives for utilities to rationalize costs, increase efficiency, and lower prices to customers.

However, as we have shown, "pure" PCR and RCR may not be politically feasible. The potential for a utility to reduce costs drastically and to earn heretofore unheard of returns may not be acceptable to regulators, intervenors, and the public. On the other hand, regulators have a responsibility to maintain the financial health of electric utilities. The possibility of bankrupcy exists under pure PCR or RCR if something unforeseen happens, such as a rapid increase in fuel prices that drastically reduce a utility's earnings, and its stock and bond prices.

To avoid these windfall gains and losses, in practice profit-sharing schemes and fail-safe points have been developed for PCR and RCR plans. These schemes typically require the stockholders of electric utilities to share high returns with their ratepayers in the form of lower rates. Losses are also typically shared. With this sharing, utilities are really not "price-takers" in the classical sense of competitive firms. They are not able to reap excessively high profits in the short run because of entrepreneurial skill or luck, nor will they suffer debilitating losses for opposite reasons.

The use of "Z" factors to pass through mandated or social costs also move utilities away from the behavior of competitive firms. For example, in some proposed and pending PBR plans, fuel-cost increases are passed through to ratepayers to varying degrees. And, although there is not enough experience to know with any degree of certainty, the rate structures of utilities subject to PCR and RCR may be adjusted after a period of time to the same level that would be obtained under COSR, with common costs allocated as shown in Figure 1.

Finally, many utilities cannot totally sever the cost-price relationship because of the existence of "regulatory assets." Statement of Financial Accounting Standard No. 71 requires that prices track costs for a utility to recover certain types of expenditures that were capitalized in the regulatory process.

With all of these adjustments to "pure" PCR and RCR that move prices closer to costs, regulators and utilities should consider the relative merits of (1) switching to a new performancebased regulatory form such as PCR and RCR or (2) simply adapting traditional COSR to the 
realities of new competitive markets. Important considerations in this decision include: (1) the complexity and administrative burden of switching to PBR; (2) the effects on a utility's stockholders and ratepayers; and (3) conformity with accounting rules. 


\section{REFERENCES}

Baumol, William J. and David F. Bradford, 1970, "Optimal Departures from Marginal Cost Pricing," American Economic Review, June.

Beesley, M.E. and S.C. Littlechild, 1989, "The Regulation of Privatized Monopolies in the United Kingdom," Rand Journal of Economics, 20(3), pp. 454-472, Autumn.

Berg, Sanford V. and Jinook Jeong, 1991, "An Evaluation of Incentive Regulation for Electric Utilities," Journal of Regulatory Economics, 3, pp. 45-55.

Berg, Sanford V. and Jinook Jeong, 1994, "An Evaluation of Incentive Regulation: Corrections," Journal of Regulatory Economics, 6(3), pp. 321-328.

Cabral, Luis M.B. and Michael H. Riordan, 1989, "Incentives for Cost Reduction Under Price-Cap Regulation," Journal of Regulatory Economics, 1(2), pp. 93-102, June.

Christensen Associates, 1994, A Price Cap Designer's Handbook, Edison Electric Institute, Washington, DC, November.

Comnes, G. Alan, 1994, Review of Performance-Based Ratemaking Plans for U.S. Gas Distribution Companies, Lawrence Berkeley Laboratory, Berkeley, California, November.

Comnes, G. Alan, Steve Stoft, Nathaniel Greene, and Lawrence J. Hill, 1995, Performance-Based Ratemaking for Electric Utilities: Review of Plans and Analysis of Economic and Resource-Planning Issues, Lawrence Berkeley Laboratory, Berkeley, California, LBL-37577, Forthcoming.

Federal Energy Regulatory Commission, 1995, Notice of Proposed Rulemaking and Supplemental Notice of Proposed Rulemaking: Promoting Wholesale Competition Through Open Access Non-Discriminatory Transmission Services and Recovery of Stranded Costs by Public Utilities and Transmitting Utilities, Docket Nos. RM95-8-000 and RM94-7-001, Washington, DC, March 29.

Hill, Lawrence J., 1995, Some Evidence of the Effects of Regulatory Design on the Financial Condition of Electric Utilities: Results from a Simulation Model, Oak Ridge National Laboratory, Oak Ridge, Tennessee, Forthcoming.

Isaac, R. Mark, 1991, "Price Cap Regulation: A Case Study of Some Pitfalls of Implementation," Journal of Regulatory Economics, pp. 193-210.

Laffont, J.J. and J. Tirole, 1993, A Theory of Incentives in Procurement and Regulation, MIT Press, Cambridge, Massachusetts.

Maine Public Utilities Commission, 1994, "Central Maine Power Company: Proposed Increase in Rates," Phase II, Docket No. 92-345, Maine Public Utilities Commission, Augusta, Maine. October 14. 
Mathios and Rogers, 1989, "The Impact of Alternative Forms of State Regulation of AT\&T on Direct-Dial, Long-Distance Telephone Rates," Rand Journal of Economics, 20(3), Autumn.

Schmalensee, Richard, 1989, "Good Regulatory Regimes," Rand Journal of Economics, 20(3), pp. 417-436, Autumn.

Thompson, Herb, Mark N. Lowry, and David A. Hovde, 1994, Total Factor Productivity in the InvestorOwned Electric Utility Industry: 1975-1992," Proceedings of the Ninth NARUC Biennial Regulatory Information Conference, Columbus, Ohio, September 7-9.

Weisman, Dennis L., 1994, "Why Less May Be More Under Price-Cap Regulation," Journal of Regulatory Economics, 6(4), pp. 339-362, December. 


\section{INTERNAL DISTRIBUTION}

1. D. C. Bauer

2. L. W. Baxter

3. V. D. Baxter

4. L. G. Berry

5. D. J. Bjornstad.

6. R. B. Braid

7. M. A. Brown

8. F. C. Chen

9. J. E. Christian

10. G. E. Courville

11. T. R. Curlee

12. P. D. Fairchild

13. S. W. Hadley.

14. S. G. Hildebrand.

15. L. J. Hill

16. E. L. Hillsman

17. E. A. Hirst

18. P. J. Hughes-

19. B. J. Kirby
20. R. M. Lee

21. P.N. Leiby

22. J. M. MacDonald

23. V. C. Mei

24. D. E. Reichle

25. D. T. Rizy

26. M. Schweitzer

27. R. B. Shelton

28. B. E. Tonn

29. J. W. Van Dyke

30. J. Vancoevering

31. J. M. Veigel (ORAU)

32. D. L. White

33. T. J. Wilbanks

34. ORNL Patent Office

35. Central Research Section

36. Document Reference Section

37. Laboratory Records (RC)

38-41. Laboratory Records Dept.

\section{EXTERNAL DISTRIBUTION}

42. Dr. Thomas E. Drabek, Professor, Department of Sociology, University of Denver, Denver, CO 80208-0209

43. Mr. George F. Sowers, P. E., Senior Vice President, Law Companies Group, Inc., 114 Townpark Drive, Suite 250, Kennesaw, GA 30144-5599

44. Dr. C. Michael Walton, Ernest H. Cockrell Centennial Chair in Engineering and Chairman, Department of Civil Engineering, University of Texas at Austin, Austin, TX 78712-1076

45-47. OSTI, U.S. Department of Energy, P. O. Box 62, Oak Ridge, TN 37831

48: Office of Assistant Manager for Energy Research and. Development, DOE/ORO, P.O. Box 2001, Oak Ridge, TN 37831-8600

49. Simon C. Hodges, Staff Economist, Virginia Power, P.O. Box 26666, Richmond, VA 23261

50-800. External Energy and Global Change Analysis Section distribution mailing list and extra copies to E. D. McFadden, 4500 N, G-23 

Lawn

Central Research Section

Building 4500N, MS-6191 

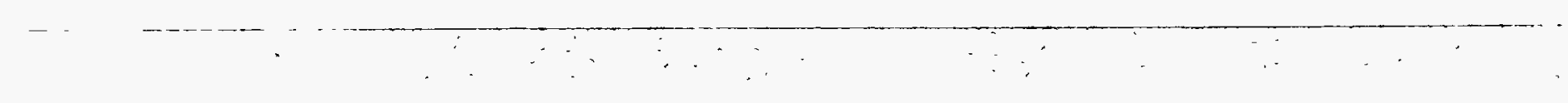